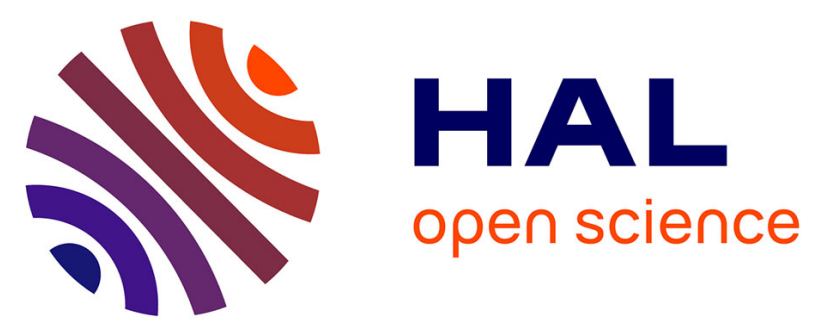

\title{
Hazard property classification of waste according to the recent propositions of the EC using different methods
}

Pierre Hennebert, Hans A. van Der Sloot, Flore Rebischung, Reinhilde

Weltens, Lieve Geerts, Ole Hjelmar

\section{- To cite this version:}

Pierre Hennebert, Hans A. van Der Sloot, Flore Rebischung, Reinhilde Weltens, Lieve Geerts, et al.. Hazard property classification of waste according to the recent propositions of the EC using different methods. Waste Management, 2014, 34 (10), pp.1739-1751. 10.1016/j.wasman.2014.05.021 . ineris-01146903

HAL Id: ineris-01146903

https://hal-ineris.archives-ouvertes.fr/ineris-01146903

Submitted on 29 Apr 2015

HAL is a multi-disciplinary open access archive for the deposit and dissemination of scientific research documents, whether they are published or not. The documents may come from teaching and research institutions in France or abroad, or from public or private research centers.
L'archive ouverte pluridisciplinaire HAL, est destinée au dépôt et à la diffusion de documents scientifiques de niveau recherche, publiés ou non, émanant des établissements d'enseignement et de recherche français ou étrangers, des laboratoires publics ou privés. 


\title{
Hazard property classification of waste according to the recent propositions of the EC using different methods
}

\author{
Pierre Hennebert ${ }^{a}$, Hans A. van der Sloot ${ }^{b}$, Flore Rebischung $^{a}$, Reinhilde Weltens ${ }^{c}$, \\ Lieve Geerts ${ }^{c}$, Ole Hjelmar ${ }^{d}$ \\ a INERIS (Institut National de l'Environnement Industriel et des Risques), BP 2, \\ 60550 Verneuil-en-Halatte, France \\ ${ }^{\mathrm{b}}$ Hans van der Sloot Consultancy, Dorpsstraat 216, 1721BV, Langedijk, The \\ Netherlands \\ ${ }^{c}$ VITO Flemish Institute for Technological Research, Boeretang 200, B 2400 Mol, \\ Belgium \\ d DHI, Agern Allé 5, DK-2970 Hørsholm, Denmark
}

\section{ABSTRACT}

Hazard classification of waste is a necessity, but the hazard properties (named " $\mathrm{H}$ " and soon "HP") are still not all defined in a practical and operational manner at EU level. Following discussion of subsequent draft proposals from the Commission there is still no final decision. Methods to implement the proposals have recently been proposed: tests methods for physical risks, test batteries for aquatic and terrestrial ecotoxicity, an analytical package for exhaustive determination of organic substances and mineral elements, surrogate methods for the speciation of mineral elements in mineral substances in waste, and calculation methods for human toxicity and ecotoxicity with $\mathrm{M}$ factors.

In this paper the different proposed methods have been applied to a large assortment of solid and liquid wastes ( $>100)$.

Data for 45 wastes - documented with extensive chemical analysis and flammability test - were assessed in terms of the different HP criteria and results were compared to LoW for lack of an independent classification. For most waste streams the classification matches with the designation provided in the LoW. This indicates that the criteria used by LoW are similar to the HP limit values.

This data set showed HP 14 'Ecotoxic chronic' is the most discriminating HP. All wastes classified as acute ecotoxic are also chronic ecotoxic and the assessment of acute ecotoxicity separately is therefore not needed. The high number of HP14 classified wastes is due to the very low limit values when stringent $M$ factors are applied to total concentrations (worst case method). With $M$ factor set to 1 the classification method is not sufficiently discriminating between hazardous and nonhazardous materials. The second most frequent hazard is HP 7 'Carcinogenic'. The 
third most frequent hazard is HP 10 'Toxic for reproduction' and the fourth most frequent hazard is HP 4 'Irritant - skin irritation and eye damage" . In a stepwise approach, it seems relevant to assess HP 14 first, then, if the waste is not classified as hazardous, to assess subsequently HP 7, HP 10 and HP 4, and then if still not classified as hazardous, to assess the remaining properties.

The elements triggering the HP14 classification in order of importance are $\mathrm{Zn}, \mathrm{Cu}$, $\mathrm{Pb}, \mathrm{Cr}, \mathrm{Cd}$ and $\mathrm{Hg}$. Progress in the speciation of $\mathrm{Zn}$ and $\mathrm{Cu}$ is essential for HP 14. Organics were quantified by the proposed method (AFNOR XP X30-489) and need no speciation. Organics can contribute significantly to intrinsic toxicity in many waste materials, but they are only of minor importance for the assessment of HP14 as the metal concentrations are the main HP14 classifiers. Organic compounds are however responsible for other toxicological characteristics (hormone disturbance, genotoxicity, reprotoxicity...) and shall be taken into account when the waste is not HP14 classified. 


\section{INTRODUCTION}

To ensure safe handling, transport, reuse and disposal, wastes are classified as nonhazardous or hazardous, and hazardous wastes are subject to special precautions and regulations. The assessment of the hazardousness of wastes in relation to their classification as non-hazardous or hazardous within the European Union is done based on Commission Decision 2000/532/EC on the List of Waste (LoW) and Annex III to Directive 2008/98/EC on waste, which defines the properties that may render a waste hazardous. Both pieces of legislation are currently under review (final versions are expected in late 2013). The main purpose of the review is to adapt the legislation to technical and scientific progress aligning it with the new chemicals legislation, i.e. Regulation (EC) No. 1272/2008 on classification, labelling and packaging of substances and mixtures (CLP 2008). However, at the same time several other amendments to the two documents have been proposed. The descriptions of and references to waste classification regulation given in this paper are based on proposals for amended versions of Commission Decision 2000/352/EC and Annex III to Directive 2008/98/EC drafted by the EU Commission in 2013 (DG ENV, 2013a and 2013b), partly resulting from the work of a group of Member State experts, carried out during 2010 to 2013. The new legislation is expected to enter into force on 1 June 2015. During a transitional period the old system can still be used, but from 2017 the $\mathrm{R}$ phrases will be fully withdrawn and replaced by hazard statements $(\mathrm{H}$ statements and EUH statements) in Annex III to the CLP with reference to Table 3.1 (List of harmonised classification and labelling of hazardous substances) in Annex VI to the CLP. The "old" R phrases are also listed in Annex VI to the CLP.

Whereas the review has resulted in several obvious improvements (e.g. a precise definition of PCBs), some of the challenges that existed in the previous (existing) EU classification regulations have been carried over into the new proposed legislation, and new challenges have been added. The assessment of each of the hazard properties is based on the content of potentially hazardous substances or on the result of a test of a given property. Just like its predecessors, the CLP has been developed for and describes the properties of pure chemicals and mixtures of pure chemicals. Waste, however, generally consists of a complex mixture of numerous substances. In many cases the approximate composition of a waste material may be known in terms of elemental constituents, while the actual forms (substances/compounds) in which they are present often are largely unknown. Since the CLP refers to well identified substances/compounds and not to elements and since practically no indication of practical procedures regarding waste classification have been provided, there is a substantial need for development of guidance and concise methodologies in this area. The inclusion of the assessment of ecotoxicity (HP14) in the proposed waste classification regulation constitutes another (new) challenge which also calls for development of practical and applicable procedures and methodologies. For some of the hazard properties that require testing, neither test methods nor requirements/limit values have been operationally defined. 
Following a brief description of the EU hazard classification rules, this paper presents and discusses some different methodologies and procedures that may be applied in practice to classification of waste materials within the framework of the expected revised EU regulation. Results of the application of some of the methods to the assessment of hazard properties of 132 solid and liquid waste materials are presented and, when possible, compared to each other and to the classifications given in the LoW. Special attention is paid to the assessment of hazard property (HP) 14: Ecotoxicity.

The hazard properties HP 9 'Infectious', HP 12 'Release of an acute toxic gas' and HP 15 'Yielding another substance', not operationally defined at the moment, are not assessed here. It is recalled that landfill acceptance criteria (EU 2003) cannot replace the hazard assessment of waste. 


\section{HAZARDOUS WASTE CLASSIFICATION}

\subsection{EU WASTE CLASSIFICATION REGULATION}

Directive 2008/98/EC defines hazardous waste as waste which displays one or more of the following hazardous properties (HPs): HP 1 Explosive, HP 2 Oxidising, HP 3 Flammable, HP 4 Irritant, HP 5 Single target organ toxicity (STOT)/Aspiration, HP 6 Acute toxicity, HP 7 Carcinogenic, HP 8 Corrosive, HP 9 Infectious, HP 10 Toxic for reproduction, HP 11 Mutagenic, HP 12 Release of an acute toxic gas cat. 1, 2 or 3, HP 13 Sensitising, HP 14 Ecotoxic, HP 15 Yielding another substance (see supplementary information for an extended description taken from the proposed amendments to Annex III in Directive 2008/98/EC (DG ENV, 2013a)).

In the CLP, a number of Hazard Categories, each corresponding to a Hazard Statement Code (HSC) are listed under each HP. The properties of a waste under assessment should be considered under each of the HPs and each of the relevant Hazard Statement Codes or measured hazardous effect. In the Commission's proposal for amendments to Decision 2000/532/EC the relevant Hazard Categories and Hazard Statement Codes are listed for each HP along with calculation rules and limit values based mostly on the content of the substances listed in the CLP under the relevant Hazard Statement Codes. It can however also be based on the results of specified experimental test protocols applied on the waste materials itself. In the supplementary information an overview is given of the various Hazard Statement Codes associated with each of the Hazard Properties.

When classifying a given waste material, each of the HSCs must be considered in relation to the relevant HP and the appropriate rules for testing or (in most cases) rules for addition of the contents of substances in the waste to be compared to limit values. If a limit value is exceeded, the waste is classified as hazardous. HSC is a hazardous property associated to pure substances/compounds which are listed in the CLP. It should be remembered that the CLP summation rules and the limit values apply to (a) all substances/compounds in the mixture and (b) to the specific compound and not to the contents of elements (if e.g. $\mathrm{ZnCl}_{2}$ is under consideration and if the measured content is $\mathrm{Zn}$, which is most often the case for waste, it should be recalculated to the corresponding content of $\mathrm{ZnCl}_{2}$ before it is entered into the summation formula. The speciation of the elements in the waste material is however often not known. For many of the HPs, so-called cut-off values apply to single substances. This means that if the content of a certain substance is lower than the cut-off value, then the content of that substance can be disregarded and will not have to be entered into the summation formula. The lowest cut-off value for single substances is $0.1 \%(\mathrm{w} / \mathrm{w})$, but when M-factors are applied this can be up to 1000 times lower for highly toxic compounds.

To facilitate the listing of substances to be considered under each HSC, the EU Commission (Joint Research Centre, Institute for Health and Consumer Protection) has established a website, http://esis.jrc.ec.europa.eu/in-dex.php?PGM=cla, where such lists can be obtained by a simple search procedure. 
The CLP methodology is a sound method for the assessment of well identified mixtures. An important shortcoming in applying the CLP methodology on (complex) waste materials is often the lack of analytical data. Alternative methods have been proposed that measure the hazardous properties of the waste materials directly and develop limits for the experimentally measured values. The most complete routine analytical data can probably be generated by the method proposed in Hennebert et al. (2013a).

\subsection{HAZARD PROPERTY ASSESSMENTS}

To classify a waste material as non-hazardous, each of Hazard Properties (HPs) and Hazard Statement Codes (HSCs) must be assessed, whereas the waste is declared hazardous as soon as soon as one of the HPs or HSCs results in a hazard classification. Further assessment may not be necessary, unless there is a requirement or desire to know exactly which properties render the waste hazardous (e.g. to ensure adequate labelling, packaging or protection measures). Knowledge of which HPs and HSCs are most critical and most likely to trigger a hazard classification for a given type of waste may therefore be used to organise a tiered approach in HP assessments for classification to minimise the effort (unless the waste ends up being classified as non-hazardous).

The classification of a waste in accordance with the revised Commission Decision 2000/532/EC is for most of the 15 HPs based on the content of one or more of the substances listed under the appropriate HSCs. For HP 1 (Explosive), HP 2 (Oxidising), and HP 3 (Flammable), wastes containing the substances listed under the associated HSCs are to be classified on the basis of tests specified in the CLP or Council regulation (EC) 440/2008. No test is currently available to assess HSC 361 : "In contact with water releases flammable gases" under HP 3, but the European standardisation committee CEN/TC 292: "Characterisation of waste" is expected to develop such a test in the near future. In addition, no operationally defined test methods exist at the moment for assessment of HP 9: "Infectious", HP 12: "Release of an acute toxic gas" and HP 15: "Yielding another substance". The remaining HPs (HP 4, HP 5, HP 6, HP 7, HP 8, HP 10, HP 11, HP 13 and HP 14) are assessed based on the contents of the substances listed in the associated HSCs. HP 14: "Ecotoxic" was (or is) not included in the existing classification requirements, and the consequences of its inclusion in the proposed legislation are expected to be important, as many chemicals are classified as H400, H410, H411 or H412.

In theory also the possibility for measuring the hazardous properties for these HPs directly on the waste is written in the waste directive, but suitable methodology is not yet available for all tests. HP14 was directly measured using ecotoxicity tests in some pilot projects (Römbke \& Pandard, ; see below) and also in vitro biotests were used for the assessment of $\mathrm{H} 5 / \mathrm{H} 6, \mathrm{H} 7 / \mathrm{H} 11$ and $\mathrm{H} 10$ (Weltens et al., 2012; Deprez et al., 2012). Practicable biological in vitro tests for human toxicity of waste are in progress (DISCRISET project, Deprez et al. 2012) and could be validated against other waste methods, like the present proposed method.

As pointed out above HSC refer to specific substances, whereas the chemical analyses of inorganic substances in waste materials generally are reported in terms of elements. In order to perform the classification assessment, it is therefore 
necessary to "translate" the content of elements to the corresponding contents of specific substances. Since many wastes are complex mixtures of many elements and substances and since many elements may occur in several substances, this is no trivial task - and at present, no guidance is provided by the EU Commission. This paper discusses some of the possible approaches that may be applied to deal with these issues.

Although not applied for the assessment of $\mathrm{H} 6$ (human toxicity) the CLP methodology using so-called M factors is applied for the HP 14 classification. M factors are used to amplify the impact of severely ecotoxic substances as a function of their experimentally determined ecotoxicity assessment of "Aquatic Acute 1" and "Chronic Acute 1". At present, $M$ factors have been officially assigned only to a few substances, but users are asked to calculate $M$ factors based on ecotoxicological effect data. It is expected, however, that for $\mathrm{H} 400$ and $\mathrm{H} 410$ substances without assigned $M$ factors, $M=1$ will be applied for waste classification until $M$ values are "officially" assigned to all relevant substances (see e.g. Hennebert et al.,, 2013a or $2013 \mathrm{~b})$. This paper also briefly discusses the calculation and assignation of $\mathrm{M}$ factors to substances based on ecotoxicological tests.

\subsection{THE LIST OF WASTE (LoW)}

The EU Commission Decision 2000/532/EC (which is under revision) includes a list waste (LoW) containing 841 specific types of waste organised in 20 main groups (two digit codes) according to origin which are further subdivided into subgroups (four digit codes) and again into specific waste types (six digit codes). Some of the specific waste types are assigned a six digit code with an asterisk, indicated that this particular waste type is classified as hazardous (absolute entry). Some waste types are assigned two different six digit codes, one with an asterisk ( $\left.\mathrm{xx} x \mathrm{xx} \mathrm{xx}^{\star}\right)$ and the addition "containing hazardous substances" indicating that the waste is hazardous, and one without an asterisk and the addition "other than those mentioned in $\mathrm{Xx} X \mathrm{X}$ $x x^{*}$, indicating that the waste is non-hazardous. Such pairs of similar waste that can be either hazardous or non-hazardous are referred to as "mirror entries", and a waste type having a mirror entry must be classified on the basis of the rules described above. Waste types in LoW that do not have mirror entries and have been assigned six digit codes without asterisks are classified as non-hazardous (absolute entries). There are 658 absolute entries and 158 mirror entries in the LoW. A EU Member State can change the classification of a waste with an absolute entry in the Low at national level if it can be justified appropriately. It should be noticed that the LoW is the result of numerous political negotiations and compromises between Member States that has also been subject to pressure from various stakeholders, and hence the LoW does not represent one concise and consistent classification methodology. LoW classification is an overall classification, taking into account all HP categories and is therefore not specifically linked to specific hazardous properties. 


\section{HAZARD ASSESSMENT METHODS}

\subsection{Method 1: "WORST CASE WITH INFORMATION"}

At the moment, the overall (pending) EU classification legislation based on the CLP is outlined in EU Commission drafts, but there is little or no guidance available on how to carry out the classification in practice, and, as already mentioned, some of the test methods and limit values to be met are also lacking. Once such methods and limit values have been established, classification according to HP1, HP2, HP3, HP9 and HP15 should be fairly straightforward. In this paper, we will not consider these hazardous properties any further (except for the assessment of HP3), but instead discuss some of the aspects associated with the classification of wastes based on the content of substances in accordance with HP4, HP5, HP6, HP7, HP8, HP10, HP11, HP13 and, in particular, HP14. Although for complex waste materials it is not easy to decide which compounds need to be measured, the selected organic substances can be measured in waste, and classification with these substances is straightforward based on their limit values under the appropriate HSCs. On the other hand the selection of (the rather limited number of) inorganic compounds is easy, but the analytical data deliver only total content for elements without further information on the speciation. Ecotoxicity is however strongly related to the speciation of the metals.

To possibly minimise the classification efforts, a first step based on a "worst case" assessment of the above hazardous properties is carried out. The procedure is based on chemical analyses of the content of a number of elements in a given waste to be considered under each of the relevant hazardous statement codes (HSCs), assuming that the total content of each element is present as the most "critical" substance, i.e. the substance containing that element that results in the highest content when recalculated from the content of the element based on the molecular formula. The method is called "worst case with information" since substances that can not be present in the waste, due to the physical-chemical conditions (i.e. acids in alkaline waste, reductants in oxidising waste, very reactive chemical products in processed waste), are not taken into account. If the waste comes out as nonhazardous when the assessment rules of each of the HPs are applied, then the waste can safely be classified as non-hazardous (based on inorganic substances). If it comes out as hazardous, then the "worst case" method may have been too conservative, and more sophisticated methods may be applied to account for the fact that the elements considered are not necessarily present as the most "critical" substances. Although the classification in this context does not include HP1, HP2, HP3, HP9, HP12 and HP15 and disregards the potential content of organic substances, the "worst case" method illustrates the principle applied and it can also provide an indication of which of the HPs most often is responsible for classification of waste as hazardous by using the hazard index, $\mathrm{HI}$ (see below). The classification rules applied are those listed in DG ENV (2013a) where the M factors for HP14 are described below. 


\subsection{Classification RULES FOR HP14}

To keep the focus on the most relevant issues, different methods will only be demonstrated for HP14 for which the (pending) assessment rules are new and also are the most complicated of all HP categories.

The proposed assessment rules for HP14 are as follows (DG ENV, 2013a):

When a waste contains a substance classified as ozone depleting and is assigned the Hazard statement Code $\mathrm{H} 420$ and such an individual substance equals or exceeds the concentration limit of $0.1 \%(\mathrm{v} / \mathrm{V})$, the waste shall be classified as hazardous by HP 14.

When a waste contains one or more substances, above the cut-off limitthat are classified as Aquatic Acute 1 and are assigned to the Hazard statement Code H40O and the sum of the concentrations of these substances equals or exceeds the concentration limit of $25 \%$, the waste shall be classified as hazardous by HP 14:

$\sum$ c Aquatic Acute $1 \geq 25 \%$

When a waste contains one or more substances classified as Aquatic Chronic 1 or 2 and is assigned to the Hazard statement Code(s) H410 or H411 and the sum of the concentrations of all substances classified as Aquatic Chronic 1 (H410) multiplied by $M * 10$ added to the sum of all substances classified as Aquatic Chronic 2 (H411) equals or exceeds the concentration limit of $25 \%$, the waste shall be classified as hazardous by HP 14:

$\left(M \times 10 \times \sum c\right.$ Aquatic Chronic 1) $+\sum c$ Aquatic Chronic 2) $\geq 25 \%$

The cut-off value for consideration in an assessment for Aquatic Acute 1 and Aquatic Chronic 1 is $0.1 / \mathrm{M} \%$ and for Aquatic Chronic 2 it is $1 \%$.

The $M$ factors ( $M_{\text {Acute }}$ and $\left.M_{\text {Chronic }}\right)$ shall be determined for each substance separately from Annex VI, Table 3.2 to the CLP. For purposes of waste classification however the chronic data are more relevant (see below).

Currently, $\mathrm{M}$ factors are available in the CLP only for very few substances (mainly pesticides). The EU Commission (Garcia Burgués, 2013) has determined that for substances for which no $M$ factors are available in the CLP, a factor of $M=1$ shall be applied (until the relevant $M$ factors have been established). Classification with $M$ factors $=1$ are discussed below.

For organic substances, a list of M factors reviewed by INERIS ecotoxicologists is available (contact the correspondence author of this paper- or preferably weblink).

For unknown inorganic substances, $M$ factors (acute and chronic) are assessed by comparing the concentration of the element in the leachate from the results of batch leaching tests (EN 12457-2) carried out on the waste with literature data on ecotoxicity tests on the same element (described in INERIS, 2013).

It is accepted that test results override calculation results. Ecotoxicological test batteries for HP14 with concentration limits are e.g. proposed in Pandard and Römbke (2013). 


\subsection{Methods 2A, B, C, D: AsSeSSING HP 14 USING BATCH LEACHING RESULTS AS SURROGATE METHODS OF SPECIATION OF THE ELEMENTS}

Different methods for HP14 for elements (when the speciation of the element is not known) are compared in this paper. Element concentrations are used rather than substances concentrations. The reason is that ecotoxic concentrations of heavy metals (the major concern) are expressed in concentrations of the elements in solution.

A first method is "Method 1: worst case with information", like for the other HPs (see above). Element concentrations are used here rather than substances concentrations, to be comparable with the methods $2 a, b, c$ and d.

Other methods are proposed and tested to attribute an ecotoxic hazard statement code to the elements (in absence of true speciation) and to choose the concentrations of elements to calculate the hazard of the waste.

Ecotoxic HSC assessment of the element: For each relevant element, the concentration in the eluate from a batch leaching test (EN 12457-2) performed at L/S $=10 \mathrm{l} / \mathrm{kg}$ on the waste in question is determined. This concentration is then compared to relevant (minimum) $\mathrm{EC}_{50}$ (for Acute Aquatic) and NOEC (for Chronic Aquatic) values for single substances. L/S is the liquid to solid ratio, i.e. the amount of water (in litres) added to an amount of waste (in $\mathrm{kg}$ ) in the batch leaching test. The $\mathrm{EC}_{50}(\mathrm{mg} / \mathrm{l})$ is the concentration of the element or substance in solution that produces the monitored biological effect (activity, mobility, dead, growth depending on the test and the biological organism) on $50 \%$ of the individuals (mobility, dead) or that produces $50 \%$ effect compared to the control (activity, growth). The no observed effect concentration NOEC $(\mathrm{mg} / \mathrm{l})$ is the highest test concentration of the element or substance in solution that produces no statistically significant effect in comparison with the control.

If the concentration is lower than one or both of those, the substance containing that element is not soluble enough to be ecotoxic and is not taken into consideration for determination of Acute Aquatic and/or Chronic Aquatic ecotoxicity.

If the concentration is equal to or higher than $\mathrm{EC}_{50}$ or NOEC, then that element is soluble enough to be ecotoxic. The hazard is then assessed using the appropriate HSCs ( $\mathrm{H} 400$ for Acute Aquatic, $\mathrm{H} 410$ and $\mathrm{H} 411$ for Chronic Aquatic). Details and reference tables are described in Hennebert et al. (2013a).

Concentrations of elements to calculate the hazard of the waste: The hazard of the waste (a mixture of substances) is calculated:

in Method 2a on the basis of the total contents of the elements (CLP method, proposed by DG ENV);

in Method 2b on the basis of the leachable contents (amount leached in the batch leaching test). 
- $\quad$ in Method 2c this is done on the basis of available content of the elements (the content extractible at $\mathrm{pH} 2$ using CEN/TS 14997 or CEN/TS 14429 at L/S = $10 \mathrm{l} / \mathrm{kg}$ for 48 hours at $20^{\circ} \mathrm{C}$ );

- in Method 2d, this is done on the basis of the maximum leachable contents (the eluates from a pH dependence leaching test (CEN/TS 14997 or $\mathrm{CEN} / \mathrm{TS}$ 14429) performed at $\mathrm{L} / \mathrm{S}=10 \mathrm{l} / \mathrm{kg}$ and a number of $\mathrm{pH}$ values in range of $\mathrm{pH}=4$ to 13$)$.

The HSC of the elements used in this method are from "worst case" substances of the element. A summary of the methods is presented at

Table 1.

Further improvements are possible on a case by case basis by determining the species of the elements. A three-tiered approach to hazard property classification of high temperature waste materials has been described by Hjelmar et al. (2013). In this method, geochemical speciation modelling using LeachXS/ORCHESTRA (van der Sloot et al., 2008) is applied on eluates obtained from a pH dependence leaching test (CEN/TS 14997 or CEN/TS 14429) performed on the waste material. The modelling results can provide information about the presence or non-presence of specific minerals/substances in the waste, thus enabling the exclusion of certain listed critical substances in the respective HSCs. For the substances shown to be present, the solubilities can be determined at selected $\mathrm{pH}$ values (at maximum solubility within a certain $\mathrm{pH}$ range) to be applied in the assessment of Acute Aquatic and Chronic Aquatic after conversion to the amounts leached of these substances. This method has not been applied here.

Table 1 : Summary of methods for HP14

\begin{tabular}{|c|c|c|c|}
\hline Method & $\begin{array}{l}\text { Hazard Statement Code assessment } \\
\text { for elements }\end{array}$ & $\begin{array}{l}\text { Element content used for Hazard } \\
\text { assessment of the waste \# }\end{array}$ & Speciation \\
\hline M1 & $\begin{array}{l}\text { Most hazardous substance (worst case) } \\
\text { of the element in the CLP table }\end{array}$ & Total & Worst case \\
\hline M2a & Leachate at own pH & Total & $\begin{array}{l}\text { Surrogate } \\
\text { method }\end{array}$ \\
\hline M2b & Leachate at own $\mathrm{pH}$ & Leachable (L/S = 10 at own $\mathrm{pH})$ & $\begin{array}{l}\text { Surrogate } \\
\text { method }\end{array}$ \\
\hline M2c & Leachate at own $\mathrm{pH}$ & Available $(\mathrm{L} / \mathrm{S}=10$ at $\mathrm{pH}=2)$ & $\begin{array}{l}\text { Surrogate } \\
\text { method }\end{array}$ \\
\hline M2d & Leachate at own $\mathrm{pH}$ & $\begin{array}{l}\text { Max of leachable }(\mathrm{L} / \mathrm{S}=10 \text { at } \mathrm{pH}=4 \\
\text { to } 13)\end{array}$ & $\begin{array}{l}\text { Surrogate } \\
\text { method }\end{array}$ \\
\hline
\end{tabular}

\# In all cases M factors have been applied

An additional method of calculation of EC50 of a mixture from the concentrations and the EC50 of the substances mixed (CLP 2008) has also been tested. This method applies only to acute ecotoxicity. Details can be found in Hennebert et al (2013c). 


\section{MATERIALS AND METHODS}

\subsection{BATTERY OF TESTS}

For HP 3 'Flammable', the tests UN N1 (flammable solids) and EC method A9 (flash point of liquids) were used (Hennebert and Rebischung 2013). A waste is hazardous if the flame propagates at a given rate (solids) or if the flash point is below $55^{\circ} \mathrm{C}$ (liquids).

For HP 14 'Ecotoxic', a battery of ecotoxicological tests and their concentration limits has been proposed by France and Germany during the discussions for the revision of the European Waste Directives (Pandard and Römbke 2013). The battery comprises aquatic and terrestrial test for one micro-organism, one aquatic and one terrestrial invertebrate and one algae or two terrestrial plants. The design of ecotoxicity tests follows a dilution approach, where waste (eluate or solid) is mixed with a control substrate (e.g. reconstituted water or artificial soil). The concentration effect relations allow to define $\mathrm{EC}_{\mathrm{x}}$ values (i.e. concentration of eluate or solid producing an effect of $\mathrm{x} \%$ ) or as LID values (= lowest ineffective dilution rate: the first dilution that does no longer produce negative effects). Limit values for $E_{\mathrm{x}}$ or $\mathrm{LID}$ are proposed. The stepwise approach begins with aquatic tests performed on waste eluates. Preparation of eluates (liquid/solid ratio $=10 \mathrm{l} / \mathrm{kg}$ dry matter, $24 \mathrm{~h}$ ) and mixtures of waste/eluate with control medium/substrate are carried out according to EN 14735. It must be noted that the $\mathrm{pH}$ of leachates are corrected (neutralised to $\mathrm{pH}=5.5$ for acid leachates and to $\mathrm{pH}=8.5$ for alkaline leachates) before the contact with the organisms. It should be realized that such a modification has consequences for element concentration and chemical form in solution (Postma et al, 2009).

\subsection{ANALYSIS METHOD}

\section{Total content:}

An original method for the determination of total elements and substances in waste up to a mass of $90 \%$ or more (AFNOR XP X30-489, Hennebert et al. 2013a) has been used for the data set DS1. The detailed results are presented in this last paper. More recent results with the method (from a service laboratory in 2012-2013) are quite satisfactory: the mean analytical mass balance is $98.8 \% \pm 5.1 \%$ for 44 solid samples, and $82.9 \% \pm 18.3 \%$ for 51 liquid samples. In the DS1, for each waste, about 200 parameters (mean value) of mineral elements and organic substances are measured. Standardized methods, including methods based on aqua regia, have been used for mineral elements content of the other data sets and in some cases also organic parameters were measured but not in a consistent way. The results are expressed per mass of dry matter for solid waste and per mass of gross weight for liquid waste.

\section{Leachable content:}


The results of classical batch leaching method (extraction of waste crushed at $4 \mathrm{~mm}$ during $24 \mathrm{~h}$ by deionised water at $10 \mathrm{l} / \mathrm{kg}$ DM ratio, EN 12457-2) have been used. The cumulated emission of percolation test (upflow column test, up to $10 \mathrm{l} / \mathrm{kg} \mathrm{DM}$, PrEN 14405) have also been used. The results are expressed per mass of dry matter for solids. The pH dependence tests (PrEN14429 and PrEN14997) are carried out at $\mathrm{L} / \mathrm{S}=10 \mathrm{l} / \mathrm{kg}$ and cover a wide range of $\mathrm{pH}$ conditions from $\mathrm{pH} 2-13$. The concentration at the natural $\mathrm{pH}$ can also be used, or the highest concentration measured over the $\mathrm{pH}$ range in the $\mathrm{pH}$ dependence test and recalculated as a mass based concentration $(\mathrm{mg} / \mathrm{kg}$ ) can be used. It reflects the availability of substances for dissolution in water under worst case conditions.

\subsection{Classification RULES}

The classification rules proposed by the DG ENV of the EU Commission are used (DG ENV $2012 \mathrm{a}$ and b). This paper uses Hazard Index (HI). Depending on HP, the $\mathrm{HI}$ is the ratio of on the one hand weighted or non-weighted sum or maximum of the concentration of relevant substances and on the other hand by the concentration(s) limit(s). If $\mathrm{HI}$ is $\geq 1$, the waste is hazardous. All the results are calculated using dry matter for solids or mass concentration for liquids. Conversion of $\mathrm{HI}$ calculated on DM to $\mathrm{HI}$ calculated on raw material or gross weight is easy with the water content.

A hazard property may have different addition rules. For example, a waste is hazardous for HP 4 'irritant - skin irritation and eye damage' if the sum or concentrations of substances with $\mathrm{H} 3141 \mathrm{~A}$ substances is $\geq 1 \%$, or if the sum of concentrations of $\mathrm{H} 318$ substances is $\geq 10 \%$, or if the sum of concentrations of substances $\mathrm{H} 315$ and $\mathrm{H} 319$ is $\geq 20 \%$. Those 3 rules are called here HP 4 A, HP 4 B and HP $4 \mathrm{C}$. In this document, the different rules of a same HP are identified by letters. Results for rules are given in Supplementary material. Synthesis by HP is given in the paper.

\subsection{Properties of Substances}

The hazard properties of the substances listed in the CLP regulation were used (Annex 3.1 of CLP version ATP02, Joint Research Centre of the EU, http://ecb.jrc.ec.europa.eu/classification-labelling/clp/ghs/downanx6.php, Excel® file version). The 4134 entries are listed with the chemical name, the EC and CAS number, the hazard statement code, the concentration limits and multiplying factors for acute ecotoxicity (M-factors) for pesticides and nickel compounds. $M$ factors for acute and chronic ecotoxicity of substances $\mathrm{H} 400$ and $\mathrm{H} 410$ are used in this paper. A list of $M$ factors for mineral substances can be found in Hennebert and Rebischung 2013. An additional list of $M$ factors for 189 (most toxic) organic substances reviewed by INERIS is available upon request to the corresponding author.

\subsection{SAMPLES OF WASTES}


Five different sets of waste samples, DS1 to DS5, have been subjected to classification by the one or more of the methods described in section 3 . The datasets have different origins and have been subjected to different types of characterisation. The wastes included in each dataset are listed in Tables 2 to 6 . Most of the waste samples shown refer to single samples, but in some cases data for several samples have been aggregated and are shown as one single entry.

Dataset DS1 is French (supplied by INERIS) and consists of 45 solid and liquid wastes covering several types of industrial and municipal waste classified as hazardous, non-hazardous and mirror entries in the LoW. They have been analysed for content of approximately 200 inorganic and organic substances with the method XP X30-489. Six additional wastes with classical analysis of organic pollutants and mineral elements are included. From those 51 samples, 26 samples have further been subjected to a leaching test (EN 12457-2).

Dataset DS2 is a literature set from Germany and France (Pandard and Römbke, 2013) and consists of 9 widely different waste types. They have been tested for the full battery of ecotoxicity tests (aquatic and terrestrial).

Dataset DS3 is Belgian (supplied by Vito) and consists of 17 wastes with some aquatic ecotoxicity tests available on both leachate (see below) and organic extracts (not shown here).

Dataset DS4 is international (from the LeachXS database, see e.g. van der Sloot et al., 2008) and consists of 19 wastes classified as hazardous, non-hazardous and mirror entries in the LoW. They have been characterised by chemical analysis for content of several elements, and they have been subjected to column leaching tests (prEN 14405) and pH dependence leaching tests (prEN 14429 or prEN 14997).

Dataset DS5 is Belgian (supplied by Vito) and consists of 32 wastes known for total content (most often the inorganic composition, data on organic compounds are limited), and for 4 of them, for leachable content of metals (EN 12457-2). Some results are mean values of large data bases on specific types of waste.

Table 2 : Data set $N^{\circ} D S 1$

\begin{tabular}{|r|l|l|c|c|}
\hline N & LoW code & Waste & $\begin{array}{c}\text { Liquid/ } \\
\text { Solid }\end{array}$ & $\begin{array}{c}\text { LoW } \\
\text { class }\end{array}$ \\
\hline 1 & 200108 or 200201 & Municipal waste - Organic fraction separately collected & Solid & NH \\
\hline 2 & Product & Compost from organic fraction separately collected & Solid & NH \\
\hline 3 & 190501 or 200301 & Mixed municipal waste, fraction $>30 \mathrm{~mm}$ after crushing & Solid & $\mathrm{NH}$ \\
\hline 4 & 190501 or 200301 & $\begin{array}{l}\text { Compost from mixed municipal waste, fraction }<30 \mathrm{~mm} \text { after } \\
\text { crushing }\end{array}$ & Solid & $\mathrm{NH}$ \\
\hline 5 & 190501 & $\begin{array}{l}\text { Non-composted organic fraction of municipal wastes }<30 \mathrm{~mm} \text { after } \\
\text { crushing, }\end{array}$ & Solid & $\mathrm{NH}$ \\
\hline 6 & $190702 *$ or 190703 & $\begin{array}{l}\text { Active landfill leachate containing hazardous substances or landfill } \\
\text { leachate other than those mentioned in } 190702\end{array}$ & Liquid & $\mathrm{M}$ \\
\hline
\end{tabular}

\footnotetext{
${ }^{1} \mathrm{H}=$ hazardous according to the European List of Waste - LoW, $\mathrm{NH}=$ non-hazardous, $\mathrm{M}=$ mirror entry, $\mathrm{NI}=$ no information
} 


\begin{tabular}{|c|c|c|c|c|}
\hline 7 & $190702 *$ or 190703 & $\begin{array}{l}\text { Closed landfill leachate containing hazardous substances or landfill } \\
\text { leachate other than those mentioned in } 190702\end{array}$ & Liquid & $\mathrm{M}$ \\
\hline 8 & 190805 & Sludges from treatment of urban waste water & Solid & $\mathrm{NH}$ \\
\hline 9 & $190205^{*}$ or 190206 & Sludges from landfill leachate, after evapo-concentration & Solid & M \\
\hline 10 & 1607 09* & $\begin{array}{l}\text { Wastes from transport tank cleaning, mixed sludge of food and } \\
\text { chemical transport }\end{array}$ & Solid & $\mathrm{H}$ \\
\hline 11 & $190107^{*}$ & MSWI Air pollution control (APC) residue, bicarbonate process & Solid & $\mathrm{H}$ \\
\hline 12 & $190107^{*}$ & MSWI APC residue, lime process & Solid & $\mathrm{H}$ \\
\hline 13 & $190105^{*}$ & MSWI fly ash & Solid & $\mathrm{H}$ \\
\hline 14 & $190107^{*}$ & APC residue industrial waste \#1 & Solid & $\mathrm{H}$ \\
\hline 15 & $190107^{*}$ & APC residue industrial waste \#2 & Solid & $\mathrm{H}$ \\
\hline 16 & $190111^{*}$ & Industrial waste bottom ash & Solid & $\mathrm{H}$ \\
\hline 17 & $100319^{*}$ & Metallic dust from aluminum industry & Solid & $\mathrm{H}$ \\
\hline 18 & No info & Packages and materials \#1 & Solid & $\mathrm{NI}$ \\
\hline 19 & $191211^{*}$ & Packages and materials \#2 & Solid & $\mathrm{H}$ \\
\hline 20 & $191211^{*}$ & Packages and materials \#3 & Solid & $\mathrm{H}$ \\
\hline 21 & $150110^{*}$ & Packages and materials \#4 & Solid & $\mathrm{H}$ \\
\hline 22 & No info & Packages and materials \#5 & Solid & $\mathrm{NI}$ \\
\hline 23 & $190813^{*}$ & Pasty waste \#1 & Solid & $\mathrm{H}$ \\
\hline 24 & No info & Pasty waste \#3 Mix of storage tank & Solid & $\mathrm{NI}$ \\
\hline 25 & $080113^{*}$ & Pasty waste \#2 & Solid & $\mathrm{H}$ \\
\hline 26 & $130208^{*}$ & Engine oil & Liquid & $\mathrm{H}$ \\
\hline 27 & $130113^{*}$ & Hydraulic oil & Liquid & $\mathrm{H}$ \\
\hline 28 & $130703^{*}$ & Hydrocarbon \#1 & Liquid & $\mathrm{H}$ \\
\hline 29 & $130507 * 130703 *$ & Hydrocarbon \#2 & Liquid & $\mathrm{H}$ \\
\hline 30 & No info & $\begin{array}{l}\text { Hydrocarbon \#3 Mixture of wastes of oils and liquid fuels without } \\
\text { motor and lubricating oil and hydraulic oil }\end{array}$ & Liquid & $\mathrm{NI}$ \\
\hline 31 & $070103 *$ & Halogenated solvent \#1 & Liquid & $\mathrm{H}$ \\
\hline 32 & No info & Halogenated solvent \#2 & Liquid & $\mathrm{NI}$ \\
\hline 33 & $140602^{*}$ & Halogenated solvent \#3 & Liquid & $\mathrm{H}$ \\
\hline 34 & $070104^{*}$ or $070204^{*}$ & Non-halogenated solvent \#1 & Liquid & $\mathrm{H}$ \\
\hline 35 & $161001^{*}$ & Waste water \#1 & Liquid & $\mathrm{H}$ \\
\hline 36 & 080416 and $110106^{*}$ & Waste water \#2, mixture of 13 wastes & Liquid & $\mathrm{H}$ \\
\hline 37 & 1912 04* & Waste water \#3 & Liquid & $\mathrm{H}$ \\
\hline 38 & No info & Waste water \#4 & Liquid & $\mathrm{NI}$ \\
\hline 39 & $161001^{*}$ & Waste water \#5 & Liquid & $\mathrm{H}$ \\
\hline 40 & $070101^{*}$ or $070201 *$ & Waste water \#6 & Liquid & $\mathrm{H}$ \\
\hline 41 & $190208^{*}$ & Liquid recovered fuel & Liquid & $\mathrm{H}$ \\
\hline 42 & $190209^{*}$ & Solid recovered fuel & Solid & $\mathrm{H}$ \\
\hline 43 & $190107^{*}$ & $\begin{array}{l}\text { APC residue from municipal waste after solid fuel, metals and } \\
\text { organic matter separation }\end{array}$ & Solid & $\mathrm{H}$ \\
\hline 44 & $110109 *$ or 110110 & Surface treatement - sludges and filter cakes & Solid & $\mathrm{M}$ \\
\hline 45 & $190111 *$ or 190112 & $\begin{array}{l}\text { Bottom ash and slag from municipal waste after solid fuel, metals } \\
\text { and organic matter separation - maturated and pretreated }\end{array}$ & Solid & $M$ \\
\hline 46 & 010309 & Bauxite residue & Solid & $\mathrm{NH}$ \\
\hline 47 & $170505 *$ or 170506 & Sediment Dunkerque (harbor, North sea) & Solid & $\mathrm{M}$ \\
\hline 48 & $170505 *$ or 170506 & Sediment Evry (highway storm basin) & Solid & $\mathrm{M}$ \\
\hline 49 & $170505 *$ or 170506 & Sediment Lens (canal, F) & Solid & $\mathrm{M}$ \\
\hline 50 & $170505 *$ or 170506 & Sediment Nimy-Blaton (canal, B) & Solid & $\mathrm{M}$ \\
\hline 51 & $170505 *$ or 170506 & Sediment Marseille (harbor, Mediterranean sea) & Solid & $\mathrm{M}$ \\
\hline
\end{tabular}

\section{Table 3 : Data set $N^{\circ} D S 2$}

\begin{tabular}{|l|l|l|c|c|}
\hline $\mathbf{N}^{\circ}$ & List of Waste code & Waste & $\begin{array}{c}\text { Liquid/ } \\
\text { Solid }\end{array}$ & $\begin{array}{c}\text { LoW } \\
\text { class }\end{array}$ \\
\hline 52 & $030104^{*}$ or 030105 & Waste wood & Solid & M \\
\hline 53 & $050103^{*}$ or 080112 & Tank bottom sludge & Solid & H \\
\hline 54 & $080111^{*}$ Dried paint & Solid & M \\
\hline
\end{tabular}




\begin{tabular}{|c|c|c|c|c|}
\hline 55 & $080111 *$ or 080112 & Waste from powder paint & Solid & $\mathrm{M}$ \\
\hline 56 & $190111 *$ or 190112 & Municipal incineration ash & Solid & $\mathrm{M}$ \\
\hline 57 & 100201 & Waste from the processing of slag & Solid & $\mathrm{NH}$ \\
\hline 58 & $100909 *$ or 100910 & Furnace dust & Solid & $\mathrm{M}$ \\
\hline 59 & $170503^{*}$ or 170504 & PAH contaminated soil & Solid & $\mathrm{M}$ \\
\hline 60 & 190805 & Sludge from treatment of urban wastewater & Solid & $\mathrm{NH}$ \\
\hline
\end{tabular}

Table 4 : Data set $N^{\circ} D S 3$

\begin{tabular}{|l|l|l|c|c|}
\hline $\mathbf{N}^{\circ}$ & \multicolumn{1}{|c|}{ LoW code } & Waste & $\begin{array}{c}\text { Liquid/ } \\
\text { Solid }\end{array}$ & $\begin{array}{c}\text { LoW } \\
\text { class }\end{array}$ \\
\hline 61 & $\begin{array}{l}190111^{*} \text { or } 1901 \\
12\end{array}$ & Bottom ashes & Solid & $\mathrm{M}$ \\
\hline 62 & $190115^{*}$ & Boiler ashes & Solid & $\mathrm{H}$ \\
\hline 63 & $\begin{array}{l}191206^{*} \text { or } 1912 \\
07\end{array}$ & Carpentry pellets & Solid & $\mathrm{M}$ \\
\hline 64 & $190813^{*}$ & Sludge & Solid & $\mathrm{H}$ \\
\hline 65 & $190113^{*}$ & Fly ashes & Solid & $\mathrm{H}$ \\
\hline 66 & $191005^{*}$ & Shredder residue & Solid & $\mathrm{H}$ \\
\hline 67 & $191005^{*}$ & Shredder residue & Solid & $\mathrm{H}$ \\
\hline 68 & $170503^{*}$ & Soil contaminated & Solid & $\mathrm{H}$ \\
\hline 69 & $170503^{*}$ & Soil contaminated & Solid & $\mathrm{H}$ \\
\hline 70 & $190813^{*}$ & Sludge & Solid & $\mathrm{H}$ \\
\hline 71 & $190117^{*}$ & Ashes & Solid & $\mathrm{H}$ \\
\hline 72 & $170503^{*}$ & Soil contaminated & Solid & $\mathrm{H}$ \\
\hline 73 & $170903^{*}$ & Construction $\&$ demolition waste & Solid & $\mathrm{H}$ \\
\hline 74 & $190813^{*}$ & Sludge & Solid & $\mathrm{M}$ \\
\hline 75 & $\begin{array}{l}190115^{*} \text { or } 1901 \\
16\end{array}$ & Filter cake inc. & Solid & $\mathrm{M}$ \\
\hline 76 & $\begin{array}{l}190113^{*} \text { or } 1901 \\
14 \text { and } 19 \text { 01 } 15^{*}\end{array}$ & Ashes inc. & Solid & $\mathrm{M}$ \\
\hline 77 & $\begin{array}{l}190205^{*} \text { or } 1902 \\
06\end{array}$ & Filter cake WWT & & \\
\hline
\end{tabular}

Table 5 : Data set $N^{\circ} D S 4$

\begin{tabular}{|l|l|l|c|c|}
\hline $\mathbf{N}^{\circ}$ & LoW code & Waste & $\begin{array}{l}\text { Liquid/ } \\
\text { Solid }\end{array}$ & $\begin{array}{l}\text { LoW } \\
\text { class }\end{array}$ \\
\hline 78 & No entry & Artificial pellets from waste & Solid & $\mathrm{NI}$ \\
\hline 79 & 190306 & Stabilized MSWI fly ash & Solid & $\mathrm{NH}$ \\
\hline 80 & 101306 & Cement kiln dust & Solid & $\mathrm{H}$ \\
\hline 81 & No entry & Compost from Municipal solid waste & Solid & $\mathrm{NI}$ \\
\hline 82 & $170505^{*}$ & Contaminated river sediment & Solid & $\mathrm{H}$ \\
\hline 83 & $170503^{*}$ & Contaminated soil (wood preservation) & Solid & $\mathrm{H}$ \\
\hline 84 & 100202 & EAF slag & Solid & $\mathrm{NH}$ \\
\hline 85 & $190111^{*}$ or 190112 & MSWI bottom ash (single sample) & Solid & $\mathrm{M}$ \\
\hline 86 & $190113^{*}$ & MSWI fly ash & Solid & $\mathrm{H}$ \\
\hline 87 & 110299 & Ni sludge & Solid & $\mathrm{H}$ \\
\hline 88 & 030399 & Incinerated paper sludge & Solid & $\mathrm{NH}$ \\
\hline
\end{tabular}




\begin{tabular}{|l|l|l|c|c|}
\hline $\mathbf{N}^{\circ}$ & LoW code & Waste & $\begin{array}{l}\text { Liquid/ } \\
\text { Solid }\end{array}$ & $\begin{array}{l}\text { LoW } \\
\text { class }\end{array}$ \\
\hline 89 & $100401 *$ or 100501 & Pb/Zn slag & Solid & M \\
\hline 90 & No entry & Recycled concrete aggregate & Solid & $\mathrm{NI}$ \\
\hline 91 & 010309 & Red mud & Solid & $\mathrm{NH}$ \\
\hline 92 & 190805 & Sewage sludge Rural & Solid & $\mathrm{NH}$ \\
\hline 93 & $100401^{*}$ or 100501 & Waelz slag & Solid & $\mathrm{M}$ \\
\hline 94 & $190111^{*}$ or 190112 & MSWI bottom ash (EU 95\% Confidence level, $\mathrm{N}>1000)$ & Solid & M \\
\hline 95 & No entry & Compost from Green waste & Solid & $\mathrm{NH}$ \\
\hline 96 & 190805 & Sewage sludge with industrial inputs & Solid & $\mathrm{NH}$ \\
\hline
\end{tabular}


Table 6 : Data set $N^{\circ} D S 5$

\begin{tabular}{|c|c|c|c|c|}
\hline $\mathbf{N}^{\circ}$ & LoW Code & Waste & $\begin{array}{l}\text { Liquid/ } \\
\text { Solid }\end{array}$ & $\begin{array}{l}\text { LoW } \\
\text { class }\end{array}$ \\
\hline 97 & 170301 or 170302 & Asphalt rubble $(n=13)$ & Solid & $\mathrm{M}$ \\
\hline 98 & 170101 & Beton rubble $(n=13)$ & Solid & $\mathrm{NH}$ \\
\hline 99 & 190116 & Boiler ashes incineration of non hazardous waste (n not known) & Solid & $\mathrm{NH}$ \\
\hline 100 & $190111 *$ and 190112 & Bottom ash (n not known) & Solid & M \\
\hline 101 & $190111 *$ and 190112 & Bottom ashes 2 (n not known) & Solid & M \\
\hline 102 & 191004 & Car shredder residue $(\mathrm{n}=10)$ & Solid & $\mathrm{NH}$ \\
\hline 103 & 200301 & Domestic waste fine fraction & Solid & $\mathrm{NH}$ \\
\hline 104 & no code & Fertilizer 1 & Solid & $\mathrm{NI}$ \\
\hline 105 & no code & Fertilizer 2 & Solid & $\mathrm{NI}$ \\
\hline 106 & $190813^{*}$ & Filter cake 14 (textile WWT) & Solid & $\mathrm{H}$ \\
\hline 107 & $190813^{*}$ & Filter cake 15 (paint WWT) & Solid & $\mathrm{H}$ \\
\hline 108 & $190813^{*}$ & Filter cake 16 (food industry WWT) & Solid & $\mathrm{H}$ \\
\hline 109 & $190813^{*}$ & Filtercake 17 (food industry WWT) & Solid & $\mathrm{H}$ \\
\hline 110 & $190813^{*}$ & Filtercake 18 (food industry WWT) & Solid & $\mathrm{H}$ \\
\hline 111 & $190813^{*}$ & Filtercake 19 (paint WWT) & Solid & $\mathrm{H}$ \\
\hline 112 & $190813^{*}$ & Filtercake 20 (paint WWT) & Solid & $\mathrm{H}$ \\
\hline 113 & 190114 & Fly ash wood incinerator & Solid & $\mathrm{NH}$ \\
\hline 114 & 190114 & Fly ashes from sludges incinerator $1(n=3)$ & Solid & $\mathrm{NH}$ \\
\hline 115 & 190114 and 190112 & Incineration ashes & Solid & $\mathrm{NH}$ \\
\hline 116 & 190812 & Industrial sludge $4(n=19)$ & Solid & $\mathrm{NH}$ \\
\hline 117 & $191301^{*}$ & Ground cleaning residue (total and leachate data) & Solid & $\mathrm{H}$ \\
\hline 118 & 191002 & Shredder 1 (total and leachate data) & Solid & $\mathrm{NH}$ \\
\hline 119 & 190814 & $\begin{array}{l}\text { Sludge of industrial waste water - other treatment (total and } \\
\text { leachate data) }\end{array}$ & Solid & $\mathrm{NH}$ \\
\hline 120 & 170504 & Soil (total and leachate data) & Solid & $\mathrm{NH}$ \\
\hline 121 & 170107 & Mixed rubble $(n=13)$ & Solid & $\mathrm{NH}$ \\
\hline 122 & 190805 & MWWTP RWZI sludge & Solid & $\mathrm{NH}$ \\
\hline 123 & 191210 & Refuse derived fuel $1(n=50)$ & Solid & $\mathrm{NH}$ \\
\hline 124 & 191210 & Refuse derived fuel 2 ( $n=500)$ & Solid & $\mathrm{NH}$ \\
\hline 125 & 191212 & Shredder 2 & Solid & $\mathrm{NH}$ \\
\hline 126 & 191212 & Shredder fluff & Solid & $\mathrm{NH}$ \\
\hline 127 & no code & Sieved sand $(n=13)$ *sand from molds used in foundries & Solid & $\mathrm{NH}$ \\
\hline 128 & 190805 & Sludge 2 Industrial & Solid & $\mathrm{NH}$ \\
\hline 129 & 190812 & Sludge from biological treatment of industrial waste water & Solid & $\mathrm{NH}$ \\
\hline 130 & 120117 & Waste blasting material & Solid & $\mathrm{NH}$ \\
\hline 131 & 191207 & Wood $(n=70)$ & Solid & $\mathrm{NH}$ \\
\hline 132 & 190805 & WWTP RWZI dried sludge $(n=93)$ & Solid & $\mathrm{NH}$ \\
\hline
\end{tabular}




\section{RESULTS AND DISCUSSION}

\subsection{OVERVIEW}

Table 7 shows an overview of the different assessment methods, the HPs for which they have been used and the datasets from which waste samples have been for hazard assessments.

Table 7 : Overview of the hazard assessment carried out in this paper

\begin{tabular}{|l|l|l|l|}
\hline $\begin{array}{l}\text { Assesment } \\
\text { method }\end{array}$ & $\begin{array}{l}\text { M factors } \\
\text { for HP14 }\end{array}$ & HP(s) assessed & $\begin{array}{l}\text { Datasets from which } \\
\text { data are used }\end{array}$ \\
\hline Tests & - & HP 3, HP14 & DS1, DS2 - DS3 \\
\hline $\begin{array}{l}\text { Method 1 } \\
\text { Worst case }\end{array}$ & Yes & $\begin{array}{l}\text { HP4, HP5 HP6, HP7, HP8, HP10, } \\
\text { HP11, HP12, HP13, HP14 }\end{array}$ & DS1 \\
\hline $\begin{array}{l}\text { Method 1 } \\
\text { Worst case }\end{array}$ & Yes & HP14 & DS1, DS4, DS5 \\
\hline Method 2a & Yes & HP14 & DS1, DS4, DS5 \\
\hline Method 2b & Yes & HP14 & DS4 \\
\hline Method 2c & Yes & HP14 & DS4 \\
\hline Method 2d & Yes & HP14 & DS4 \\
\hline
\end{tabular}

In the following, the results of hazard assessments using each of the methods listed in Table 7 are presented and discussed. For each criterion to be assessed for the HPs, a "Hazard Index" $(\mathrm{HI})$ is defined as the ratio between the calculated result according to a given rule under an HP and the limit value for that rule. For HPs with more than one rule of calculation with associated limit values, only the maximum $\mathrm{HI}$ value is presented as it defines the classification of the waste. If the maximum $\mathrm{HI}$ is larger than or equal to 1, the waste is classified as hazardous, otherwise as nonhazardous according to the HP in question.

\subsection{BATTERY OF TEST HP 3 'FLAMmABLE' AND TEST HP 14 'ECOTOXIC'}

All the solid and liquid wastes containing organic matter or solvent of the DataSet \#1 have been tested for flammability. None of the solid wastes were flammable and 4 liquid wastes have a flash point $<55^{\circ} \mathrm{C}$ (waste \# 32 , 33, 34 and 41 - Table 10).

On 9 wastes Pandard and Römbke (2013) have applied a battery of 3 aquatic ecotoxicity tests on the leachate fraction and 2 terrestrial tests on the solid fraction. They used LID limit values as proposed during the discussions for the revision of the European Waste Directives. The results are synthesized in Table 8. The test battery is used in particular to assess the hazardousness of waste in cases of mirror entries in the LoW. 
Table 8 : HP 14 tested by both aquatic and terrestrial ecotoxicological test batteries on respectively leachat and bulk fractions (9 samples, DS2, Pandard and

Römbke 2013)

\begin{tabular}{|l|c|c|}
\hline & Tested non $\mathrm{H}$ & Tested $\mathrm{H}$ \\
\hline LoW hazardous & - & 1 \\
\hline LoW non-hazardous & 2 & - \\
\hline LoW Mirror & 2 & 4 \\
\hline No information & - & - \\
\hline
\end{tabular}

In the group of the hazardous wastes, four are hazardous for both aquatic and terrestrial test systems, and one (municipal incineration ash) is hazardous for the aquatic test systems only.

Also at VITO leachate fractions of 17 samples were tested for their aquatic ecotoxicity using the same 3 ecotoxicity tests.

Table 9 : HP14 tested by partial aquatic ecotoxicological test battery on leachate fraction (17 samples, DS3)

\begin{tabular}{|l|c|c|}
\hline \multirow{2}{*}{ LoW hazardous } & Tested non $\mathrm{H}$ & Tested $\mathrm{H}$ \\
\hline LoW non-hazardous & - & 5 \\
\hline LoW Mirror & 3 & - \\
\hline No information & - & 1 \\
\hline
\end{tabular}

Algae were often the most sensitive species for leachate toxicity. It can be concluded that a full ecotoxicological test battery should be used.

\subsection{CLASSIFICATION BY EXTENSIVE CHEMICAL ANALYSIS (TOTAL CONTENT) AND WORST CASE METHOD AND COMPARISON TO LOW CLASSIFICATION}

The data used for hazard classification include concentrations of identified organic substances, and concentrations of elements of the first 45 waste of DS1. The classifications presented in Table 10 are "worst case with information" for elements (including for HP 14), and should be improved by true knowledge and speciation of minerals in the waste. In this table, the figures correspond with calculated Hazard Index $(\mathrm{HI})$. The $\mathrm{HI}$ is the sum or the maximum (depending on the classification rule) of ratio between hazardous substances concentrations and their concentration limits (weighted). If $\mathrm{HI}$ is higher than 1 , the waste is classified as hazardous. A synthesis is presented in Table 11. The cut-off values have not been used for this exercise, but their use does not modify the results (results not shown). 
Table 10 : Classification of waste by flammability test and chemical analysis for 45 waste of DS1 (hazard index)

\begin{tabular}{|c|c|c|c|c|c|c|c|c|c|c|c|c|c|}
\hline$\#$ & Waste & $\begin{array}{c}\text { HP } \\
3\end{array}$ & HP 4 & HP 5 & \begin{tabular}{|c|} 
HP \\
6 \\
\end{tabular} & HP 7 & $\begin{array}{c}\mathrm{HP} \\
8 \\
\end{array}$ & HP 10 & $\begin{array}{l}\text { HP } \\
11\end{array}$ & $\begin{array}{l}\text { HP } \\
13\end{array}$ & HP 14 & $\begin{array}{l}\text { Hazar } \\
\text { dous }\end{array}$ & $\mathrm{n} \mathrm{HP}$ \\
\hline 1 & $\begin{array}{l}\text { Municipal waste MW - } \\
\text { Organic fraction sep. } \\
\text { collected }\end{array}$ & & 0.89 & 0.03 & 0.05 & 0.30 & 0.18 & 0.10 & 0.03 & 0.00 & 0.09 & & 0 \\
\hline 2 & $\begin{array}{l}\text { Compost from organic } \\
\text { fraction sep. collected }\end{array}$ & & 0.12 & 0.03 & 0.11 & 0.05 & 0.00 & 0.02 & 0.01 & 0.00 & 0.19 & & 0 \\
\hline 3 & $\mathrm{MW}$ fraction $>30 \mathrm{~mm}$ & & 0.07 & 0.09 & 0.10 & 1.38 & 0.07 & 0.46 & 0.14 & 0.01 & 1.27 & $\mathrm{H}$ & 2 \\
\hline 4 & $\begin{array}{c}\text { Compost from MW, } \\
\text { fraction }<30 \mathrm{~mm}\end{array}$ & & 0.11 & 0.01 & 0.10 & 0.07 & 0.00 & 0.04 & 0.01 & 0.00 & 0.33 & & 0 \\
\hline 5 & $\begin{array}{l}\text { Non-composted organic } \\
\text { fraction of } \mathrm{MW}<30 \mathrm{~mm}\end{array}$ & & 0.13 & 0.06 & 0.13 & 0.57 & 0.14 & 0.19 & 0.06 & 0.01 & 0.83 & & 0 \\
\hline 6 & Active landfill leachate & & 0.21 & 0.06 & 0.09 & 0.04 & 0.28 & 0.01 & 0.00 & 0.00 & 0.05 & & 0 \\
\hline 7 & Closed landfill leachate & & 0.00 & 0.00 & 0.00 & 0.00 & 0.00 & 0.00 & 0.00 & 0.00 & 0.00 & & 0 \\
\hline 8 & $\begin{array}{c}\text { Sludges from treatment } \\
\text { of urban waste water }\end{array}$ & & 0.27 & 0.02 & 0.24 & 0.11 & 0.00 & 0.04 & 0.02 & 0.00 & 0.29 & & 0 \\
\hline 9 & $\begin{array}{c}\text { Sludges from landfill } \\
\text { leachate }\end{array}$ & & 0.37 & 0.01 & 0.15 & 0.09 & 0.01 & 0.03 & 0.01 & 0.00 & 0.05 & & 0 \\
\hline 10 & $\begin{array}{l}\text { Wastes from transport } \\
\text { tank cleaning, mixed }\end{array}$ & & 0.14 & 0.06 & 0.11 & 0.65 & 0.00 & 0.22 & 0.06 & 0.01 & 1.13 & $\mathrm{H}$ & 1 \\
\hline 11 & $\begin{array}{l}\text { MSWI Air pollution } \\
\text { control (APC) }\end{array}$ & & t & 0.02 & 0.36 & 0.19 & 0.32 & 0.59 & 0.20 & 0.00 & 9.84 & $\mathrm{H}$ & 2 \\
\hline 12 & MSWI APC residue & & 2.38 & 0.02 & 0.35 & 0.72 & 0.31 & 0.23 & 0.16 & 0.00 & 7.92 & $\mathrm{H}$ & 2 \\
\hline 13 & MSWI fly ash & & 2.70 & 0.03 & 0.59 & 0.36 & 0.82 & 1.14 & 0.34 & 0.00 & 20.49 & $\mathrm{H}$ & 3 \\
\hline 14 & $\begin{array}{l}\text { APC residue industrial } \\
\text { waste } \# 1\end{array}$ & & 0.96 & 0.10 & 0.41 & 1.02 & 0.67 & 3.22 & 0.22 & 0.00 & 16.94 & $\mathrm{H}$ & 3 \\
\hline 15 & $\begin{array}{c}\text { APC residue industrial } \\
\text { waste } \# 2\end{array}$ & & 0.47 & 0.09 & 0.35 & 0.99 & 0.62 & 14 & 0.21 & 0.01 & 3.84 & $\mathrm{H}$ & 2 \\
\hline 16 & $\begin{array}{l}\text { Industrial waste bottom } \\
\text { ash }\end{array}$ & & 0.66 & 0.30 & 0.89 & 1.16 & 1.05 & 1.01 & 0.30 & 0.03 & 19.50 & $\mathrm{H}$ & 4 \\
\hline 17 & $\begin{array}{l}\text { Metallic dust from } \\
\text { aluminum industry }\end{array}$ & & 2.62 & 0.06 & 0.14 & 0.03 & 0.26 & 0.10 & 0.10 & 0.00 & 0.35 & $\mathrm{H}$ & 1 \\
\hline 18 & $\begin{array}{l}\text { Packages and materials } \\
\text { PM \#1 }\end{array}$ & & 0.23 & 0.06 & 0.25 & 0.05 & 0.33 & 0.20 & 0.61 & 0.01 & 2.88 & $\mathrm{H}$ & 1 \\
\hline 19 & $\mathrm{PM} \# 2$ & & 0.17 & 0.05 & 0.28 & 0.03 & 0.31 & 0.15 & 0.46 & 0.00 & 278.46 & $\mathrm{H}$ & 1 \\
\hline 20 & PM \#3 & & \begin{tabular}{|l|}
0.30 \\
\end{tabular} & 0.18 & 0.44 & 39.86 & 0.29 & 0.59 & 1.78 & 0.02 & 5.54 & $\mathrm{H}$ & 3 \\
\hline 21 & PM \#4 & & \begin{tabular}{|l|}
0.14 \\
\end{tabular} & 0.09 & 0.23 & 0.80 & 0.16 & 0.29 & 0.87 & 0.01 & 2.05 & $\mathrm{H}$ & 1 \\
\hline 22 & PM \#5 & & 0.82 & 0.12 & 0.39 & 0.00 & 0.64 & 0.17 & 0.51 & 0.01 & 4.49 & $\mathrm{H}$ & 1 \\
\hline 23 & Pasty waste \#1 & & 0.13 & 0.03 & 0.27 & 0.01 & 0.06 & 0.05 & 0.15 & 0.00 & 0.82 & & 0 \\
\hline 24 & Pasty waste \#3 & & \begin{tabular}{|l|}
0.45 \\
\end{tabular} & 0.13 & 0.13 & 0.03 & 0.65 & 0.41 & 0.12 & 0.00 & 1.15 & $\mathrm{H}$ & 1 \\
\hline 25 & Pasty waste \#2 & & 0.35 & 0.07 & 0.27 & 0.72 & 0.28 & 0.24 & 0.71 & 0.05 & 8.82 & $\mathrm{H}$ & 1 \\
\hline 26 & Engine oil & & 0.04 & 0.01 & 0.07 & 1.71 & 0.00 & 0.57 & 0.17 & 0.02 & 0.79 & $\mathrm{H}$ & 1 \\
\hline 27 & Hydraulic oil & & 0.07 & 0.03 & 0.07 & 0.08 & 0.01 & 0.01 & 0.01 & 0.00 & 0.00 & & 0 \\
\hline 28 & Hydrocarbon \#1 & & 0.04 & 0.01 & 0.30 & 0.61 & 0.00 & 0.01 & 0.01 & 0.01 & 2.54 & $\mathrm{H}$ & 1 \\
\hline 29 & Hydrocarbon \#2 & & 0.18 & 0.02 & 0.22 & 0.12 & 0.10 & 0.06 & 0.18 & 0.05 & 0.32 & & 0 \\
\hline 30 & Hydrocarbon \#3 Mixture & & 0.00 & 0.00 & 0.05 & 0.06 & 0.00 & 0.01 & 0.01 & 0.00 & 0.00 & & 0 \\
\hline 31 & Halogenated solvent \#1 & & \begin{tabular}{|l|}
0.44 \\
\end{tabular} & 0.23 & 1.12 & 43.62 & 0.10 & 0.01 & 0.66 & 0.00 & 0.05 & $\mathrm{H}$ & 2 \\
\hline 32 & Halogenated solvent \#2 & $x$ & 0.44 & 0.00 & 0.09 & 0.13 & 0.00 & 0.01 & 0.01 & 0.00 & 0.00 & $\mathrm{H}$ & 1 \\
\hline 33 & Halogenated solvent \#3 & $\mathrm{x}$ & 0.02 & 0.02 & 0.06 & 80.86 & 0.04 & 0.64 & 0.01 & 0.00 & 0.62 & $\mathrm{H}$ & 2 \\
\hline 34 & $\begin{array}{l}\text { Non-halogenated } \\
\text { solvent \#1 }\end{array}$ & $\mathrm{x}$ & 0.84 & 0.86 & 65 & 0.17 & 0.19 & 2.87 & 0.02 & 0.02 & 0.87 & $\mathrm{H}$ & 3 \\
\hline 35 & Waste water \#1 & & 0.15 & 0.00 & 0.08 & 0.17 & 0.20 & 0.01 & 0.01 & 0.00 & 0.04 & & 0 \\
\hline 36 & Waste water \#2 & & 0.02 & 0.00 & 0.04 & 0.17 & 0.03 & 0.01 & 0.01 & 0.00 & 0.01 & & 0 \\
\hline 37 & Waste water \#3 & & 0.00 & 0.00 & 0.04 & 0.06 & 0.01 & 0.01 & 0.01 & 0.00 & 0.00 & & 0 \\
\hline 38 & Waste water \#4 & & 0.54 & 0.57 & 1.37 & 5.90 & 0.14 & 1.90 & 5.70 & 0.06 & 0.28 & $\mathrm{H}$ & 4 \\
\hline 39 & Waste water \#5 & & 0.00 & 0.00 & 0.07 & 0.17 & 0.01 & 0.01 & 0.01 & 0.00 & 0.00 & & 0 \\
\hline 40 & Waste water \#6 & & \begin{tabular}{|l|}
0.07 \\
\end{tabular} & 0.00 & 0.07 & 0.72 & 0.10 & 0.01 & 0.02 & 0.00 & 0.16 & & 0 \\
\hline 41 & Liquid recovered fuel & $\mathrm{x}$ & 0.23 & 0.06 & \begin{tabular}{|l|l|}
0.17 \\
\end{tabular} & 0.59 & 0.34 & 0.33 & 0.04 & 0.04 & 0.28 & $\mathrm{H}$ & 1 \\
\hline
\end{tabular}




\begin{tabular}{|c|c|c|c|c|c|c|c|c|c|c|c|c|c|}
\hline 42 & Solid recovered fuel & & 0.39 & 0.09 & 0.24 & 0.92 & 0.13 & 0.47 & 0.94 & 0.01 & 4.10 & $\mathrm{H}$ & 1 \\
\hline 43 & $\begin{array}{c}\text { APC residue from } \\
\text { municipal waste }\end{array}$ & & 1.03 & 0.02 & 0.47 & 1.06 & 0.01 & 0.59 & 0.25 & 0.00 & 7.35 & $\mathrm{H}$ & 3 \\
\hline $\begin{array}{c}\text { Surface treatement - } \\
\text { sludges and filter cakes }\end{array}$ & & 3.88 & 32.68 & 6.34 & 326.79 & 0.48 & 108.93 & 32.68 & 3.27 & 48.22 & $\mathrm{H}$ & 8 \\
\hline 45 & $\begin{array}{c}\text { Bottom ash and slag } \\
\text { from municipal waste }\end{array}$ & & 0.57 & 0.09 & 0.25 & 0.26 & 0.02 & 0.56 & 0.90 & 0.01 & 6.49 & $\mathrm{H}$ & 1 \\
\hline $\begin{array}{l}\mathrm{n}> \\
1\end{array}$ & & 4 & 6 & 1 & 4 & 10 & 1 & 7 & 3 & 1 & 20 & & 28 \\
\hline
\end{tabular}

Table 11 : Summary table of hazard of waste (45 waste of DS1)

\begin{tabular}{|l|c|c|c|c|}
\hline Hazard Property & $\begin{array}{l}\text { Hazardous } \mathbf{n} \text { of } \\
\text { waste }\end{array}$ & $\begin{array}{l}\text { Hazard Index } \\
\text { median }\end{array}$ & $\begin{array}{l}\text { HI } \\
\mathbf{9 0 \%}\end{array}$ & $\begin{array}{l}\text { HI } \\
\text { max }\end{array}$ \\
\hline HP 14 Ecotoxic & 20 out of 45 & 0.82 & 16.9 & 278 \\
\hline HP 7 Carcinogenic & 10 out of 45 & 0.30 & 5.90 & 326 \\
\hline HP 10 Toxic for reproduction & 7 out of 45 & 0.19 & 1.90 & 109 \\
\hline $\begin{array}{l}\text { HP 4 Irritant - skin irritation and eye } \\
\text { damage }\end{array}$ & 6 out of 45 & 0.23 & 2.38 & 3.88 \\
\hline HP 6 Acute toxicity & 4 out of 45 & 0.22 & 0.89 & 6.34 \\
\hline HP 3 Flammable & 4 out of 45 & (test) & - & - \\
\hline HP 11 Mutagenic & 3 out of 45 & 0.12 & 0.90 & 33 \\
\hline $\begin{array}{l}\text { HP 5 Specific target organ toxicity / } \\
\text { Aspiration }\end{array}$ & 1 out of 45 & 0.03 & 0.23 & 33 \\
\hline HP 8 Corrosive & 1 out of 45 & 0.13 & 0.64 & 1.05 \\
\hline HP 13 Irritant & 1 out of 45 & 0.00 & 0.04 & 3.27 \\
\hline
\end{tabular}

The most frequent hazard is HP 14 Ecotoxic. Ecotoxic 'chronic' (20 wastes out of 45) is much more frequent than ecotoxic acute' (7 out of 45 ) (results shown in Supplementary Information). The wastes classified as ecotoxic acute are always classified as ecotoxic chronic.

The second most frequent hazard is HP 7 'Carcinogenic' (10 out of 45). The concentration limit for individual $\mathrm{H} 350$ substances is max $0.1 \%$. The third most frequent hazard is HP 10 'Toxic for reproduction' (7 out of 45). The concentration limit for individual $\mathrm{H} 360$ substances is max $0.3 \%$. The fourth most frequent hazard is HP 4 'Irritant - skin irritation and eye damage' (6 out of 45) with sum of H315 and 319 substances it is 9 out of 45 .

In a stepwise approach, it seems relevant to assess HP 14 first. If the waste is not classified as hazardous by HP 14, then HP 7 'carcinogenic' and HP 10 'toxic for reproduction' and HP 4 'Irritant - skin irritation and eye damage' could be evaluated, since they are the more frequently encountered hazard properties in this waste panel. These properties are, to our knowledge, in the current practice assessed only by judgment with information on the origin (process, raw material) of the waste. Practicable biological tests are proposed (DISCRISET project, Deprez et al. 2012) but not fully validated against other methods at the moment.

For HP 14 'Ecotoxic chronic', the elements triggering the classification are, by decreasing frequency of contribution to the $\mathrm{HI}$ when $>0.1: \mathrm{Zn}$ (25 out of the 45 wastes ), $\mathrm{Cu}$ (16 out of 45), $\mathrm{Pb}$ (11 out of 45$), \mathrm{Cr}$ (10 out of 45$), \mathrm{Cd}$ (9 out of 45$), \mathrm{Hg}$ 
(7 out of 45 ), $\mathrm{Co}$ (6 out of 45$), \mathrm{Ni}(2$ out of 45$)$. $\mathrm{Pb}, \mathrm{Cd}$ and $\mathrm{Hg}$ have generic entries (see supplementary information) and no further speciation is necessary. Chromium(VI) can be detected by $\mathrm{EN} 15192$ and $\mathrm{Cr}$ (III) is not classifying. The speciation of $\mathrm{Zn}$ and $\mathrm{Cu}$ are essential for HP 14. Organics are quantified by the proposed method (AFNOR XP X30-489) and need no speciation, but can contribute significantly to intrinsic toxicity in many waste materials (Deprez et al. 2012).

For human toxicity HPs (other than HP14), in the "worst case with information" method used as surrogate for speciation of elements, for 45 waste, the elements with a Hazard Index $\geq 0.1$ are : $\mathrm{Pb}$ (3 wastes out of 45,2 different HPs: 7,10$), \mathrm{Zn}(7 \%$ of the waste, 2 different HPs: 4, 8), Co (3 wastes out of 45, $1 \mathrm{HP}: 7$ ), Ni (2 wastes out of 45, 7 different HPs: 4, 5, 6, 7, 10, 11, 13), $\mathrm{Cr}(\mathrm{VI})$ (2 wastes out of 45, 5 different HPs: $5,6,7,10,11)$. $\mathrm{Pb}$ has a generic entry and $\mathrm{Cr}(\mathrm{VI})$ is detected by EN 15192. So speciation of $\mathrm{Zn}, \mathrm{Co}$ and $\mathrm{Ni}$ are important for human toxicity assessment.

Hazard properties are frequently associated, as shown at Figure 1:17 wastes are not hazardous, 12 waste are hazardous for one HP, 7 waste are hazardous for 2 HPs, 5 for 3 HPs and 2 for $4 \mathrm{HPs}$. A heavily PCB contaminated sediment is hazardous for 8 HPs.

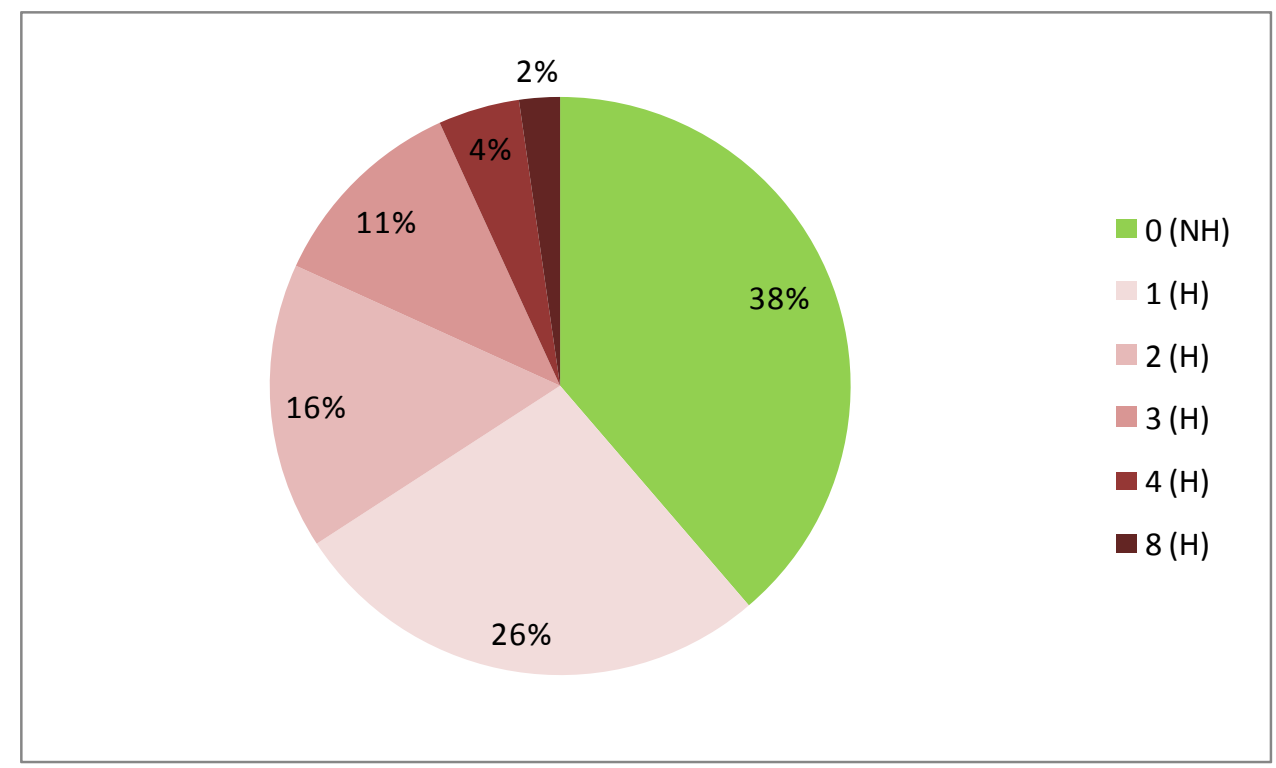

Figure 1 : Number of HP (calculated as hazardous) by waste $(n=45)$

The correspondence between the obtained classification and the LoW classification is presented in Table 12 and Figure 2. Despite the "worst case with information" approach, the classifications by European list of waste (LoW) and by the chemical composition using the proposed rules are similar. The comparison between the two classification methods indicates that: 
- the two classification methods match in over half of all cases (25 out of 45 wastes);

- in $25 \%$ of the cases, the calculation method provides a classification, where LoW does not(Mirror or No Information);

- in $20 \%$ of cases, the two classification methods are not in agreement (9 out of 45). For one data set, the calculated classification is more severe than LoW; in other cases (8 out of 45) the LoW is more stringent than the calculated classification.

These results show that the choices made for LoW classification are comparable and reflect the presence of hazardous compounds in the waste mixture in general. Discrepancies can be explained by the fact that the LoW classifies the waste materials based on the type of waste (i.e; designated by consensus) and not on measurement of individual batches of a classified waste type.

Table 12 : Correspondence between tested (HP 3) or calculated (other HPs) classification and LoW classification

\begin{tabular}{|l|c|c|c|}
\hline & Calculated NH & Calculated H & Discrepant Wastes \\
\hline LoW Hazardous & 8 & 20 & 8: \#23, 27, 29, 35, 36, 37, 39, 40 \\
\hline LoW non-hazardous & 5 & 1 & $1: \# 3$ \\
\hline LoW Mirror & 3 & 2 & - \\
\hline No information & 1 & 5 & - \\
\hline
\end{tabular}

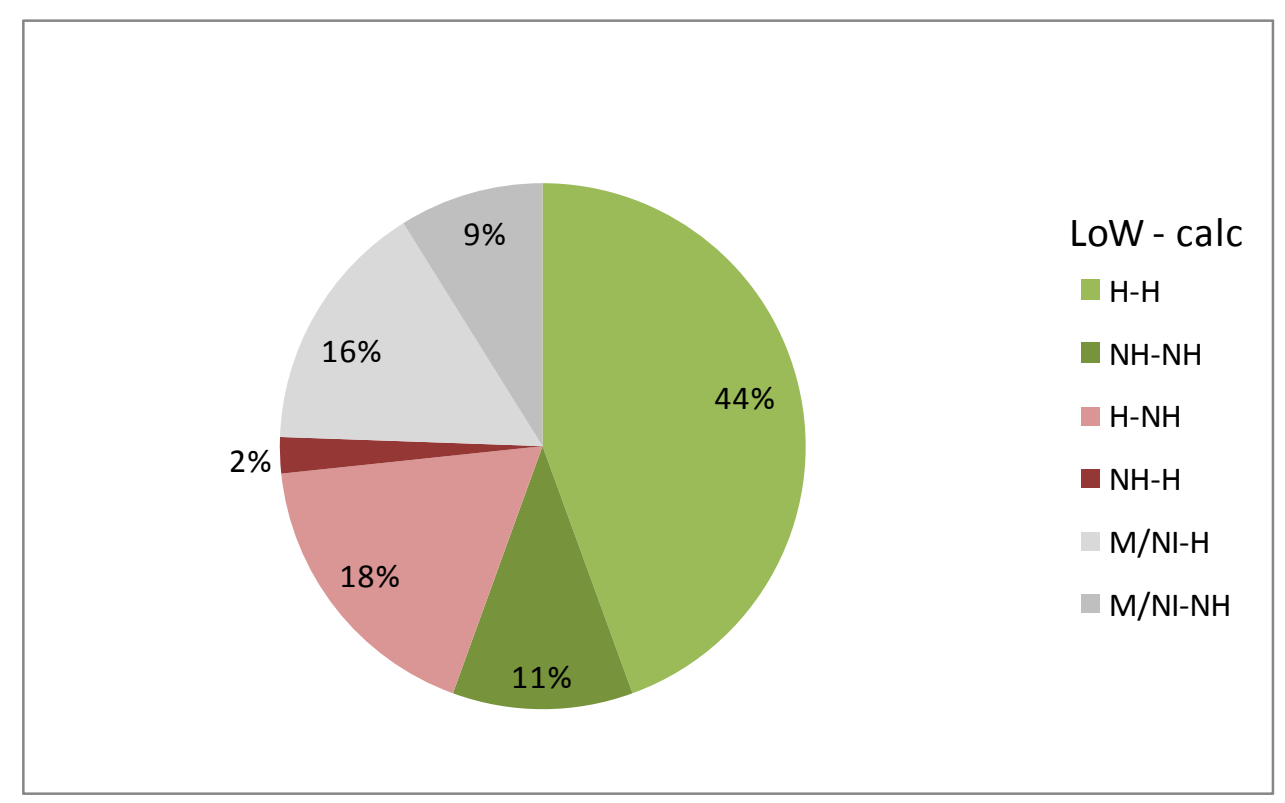


Figure 2 : Similarities in the classification for HP 1 to HP 14 (excepted HP 9, HP 12 and HP 15) by tested and calculated hazard from exhaustive composition data, and by European List of Waste (45 waste)

Biotests can be very useful tools to measure the presence of mixtures with adverse effects: they will have to be applied to different fractions (inorganic, organic, aquatic, terrestrial, acute and chronic) to enable full assessment of the toxicological properties of the waste materials.

\subsection{COMPARISON OF METHODS FOR HP 14}

The summary classification of waste from DS1, DS4 and DS 5 with leachate composition are given at Table 13. Details are given in Supplementary information.

Table 13 : Classification for HP14 with different methods (45 wastes with element total and leachable concentration from DS1, DS4 and DS5, and 19 wastes of DS4, organic substances not taken into account)

\begin{tabular}{|c|c|c|c|c|c|c|}
\hline HP 14 & N Waste & $\begin{array}{l}\text { Hazardous } \\
\text { with Worst } \\
\text { case method } \\
\text { (Method 1) }\end{array}$ & $\begin{array}{l}\text { Hazardous by total } \\
\text { concentration if } \\
\text { leachate } \\
\text { concentration > } \\
\mathrm{EC}_{50} \text { (Method 2a) }\end{array}$ & $\begin{array}{l}\text { Hazardous by } \\
\text { leachate } \\
\text { concentration if } \\
\text { leachate } \\
\text { concentration > } \mathrm{EC}_{50} \\
\text { (Method } 2 \mathrm{~b} \text { ) }\end{array}$ & $\begin{array}{l}\text { Hazardous by } \\
\text { available } \\
\text { concentration if } \\
\text { leachate } \\
\text { concentration > } \\
\mathrm{EC}_{50} \text { (Method 2c) }\end{array}$ & $\begin{array}{l}\text { Hazardous by } \\
\text { maximum of } \\
\text { leachate } \\
\text { concentration } \mathrm{pH} \\
4-13 \text { if leachate } \\
\text { concentration > } \\
\mathrm{EC}_{50} \text { (Method 2d) }\end{array}$ \\
\hline Acute & 45 & 9 & 4 & 0 & No data & No data \\
\hline Chronic & 45 & 28 & 25 & 0 & No data & No data \\
\hline Chronic & 19 & 12 & 10 & 0 & 4 & 4 \\
\hline
\end{tabular}

For 19 wastes of DS4 (Table 14) assessed for HP14 chronic, 12 are hazardous by "worst case method" (Method 1), 10 by total concentration if leachate concentration > EC50 (Method 2a), 0 by leachate concentration (Method 2b), 4 by available concentration (extractable at $\mathrm{pH}$ 2) if leachate concentration > EC50 (Method 2c) and 4 by method $2 \mathrm{~d}$.

Table 14 : Hazard Index for HP14 chronic with different methods (DS4, 19 wastes with element total, leachable at own $\mathrm{pH}$, available, leachable $\mathrm{pH}$ 4-12 concentrations, organic substances not taken into account).

\begin{tabular}{|l|r|r|r|r|r|}
\hline Sample / Method & M1 & M2a & M2b & M2c & M2d \\
\hline Artificial pellets $\mathrm{pH}$ & 0.42 & 0.06 & 0.00 & 0.00 & 0.08 \\
\hline Cement Kiln dust & 6.1 & 6.16 & 0.16 & 4.0 & 3.7 \\
\hline Compost from Green waste & 0.17 & 0.176 & 0.00 & 0.00 & 0.00 \\
\hline Compost from MSW EU & 1.5 & 1.476 & 0.00 & 0.18 & 0.18 \\
\hline
\end{tabular}




\begin{tabular}{|l|r|r|r|r|r|}
\hline Cont Soil Wood preservation & 0.75 & 0.30 & 0.00 & 0.09 & 0.27 \\
\hline Nickel sludge wet & 1.45 & 0.76 & 0.00 & 0.16 & 0.16 \\
\hline Pb Zn Slag & 37.6 & 30.0 & 0.00 & 2.1 & 2.9 \\
\hline Recycled Concrete Aggr & 0.00 & 0.00 & 0.00 & 0.00 & 0.10 \\
\hline Red Mud TS14429 red & 0.13 & 0.13 & 0.00 & 0.00 & 0.00 \\
\hline River sediment Rhine Harbour & 2.0 & 2.0 & 0.18 & 0.17 & 0.17 \\
\hline Sewage sludge Rural & 0.48 & 0.48 & 0.00 & 0.00 & 0.00 \\
\hline Waelz slag & 33.0 & 4.8 & 0.00 & 0.80 & 0.22 \\
\hline Paper Sludge fly ash & 1.66 & 0.32 & 0.00 & 0.00 & 0.39 \\
\hline EAF slag & 35.4 & 35.4 & 0.00 & 0.00 & 0.00 \\
\hline CCA preserved wood IWO1 & 0.58 & 0.58 & 0.00 & 0.29 & 0.29 \\
\hline MSWI Fly ash pH & 6.38 & 6.3 & 0.41 & 5.5 & 4.8 \\
\hline SS MSWI FA & 6.1 & 6.1 & 0.65 & 4.45 & 4.41 \\
\hline Sewage sludge industrial & 1.09 & 1.09 & 0.00 & 0.23 & 0.23 \\
\hline MSWI Bottom ash EU & 4.5 & 2.9 & 0.00 & 0.995 & 0.98 \\
\hline Nb samples HI > & 12 & 10 & 0 & 4 & 4 \\
\hline
\end{tabular}

The calculation of hazard by leachate concentration doesn't classify any tested waste and seems not recommended. The calculation of hazard by available concentration $(\mathrm{pH}$ 2) or maximum of leachate concentration $(\mathrm{pH} 4-13)$ are less severe than Method 1 and 2a. In case of EAF slag all $\mathrm{Cr}$ is present as $\mathrm{Cr}(\mathrm{III})$ and hence not leachable at $\mathrm{pH} 2$ and $\mathrm{L} / \mathrm{S}=10$. For Waelz slag a similar situation exists that $\mathrm{Pb}$ and $\mathrm{Zn}$ are in corporated in the silicate matrix and hence non-leachable at low $\mathrm{pH}$. Further chemical speciation work and cross-checking with ecotoxicological results should be done for all the methods. Methods based on leachate concentrations could be very useful in a risk approach of a given scenario.

As expected from a toxicological point of view more wastes are classified as hazardous for HP 14 chronic than for HP 14 acute, and all HP14 acute samples are also HP14 chronic.

For HP 14 acute, the method with calculation of $\mathrm{EC}_{50}$ of a mixture from the concentrations and $\mathrm{EC}_{50}$ of substances has always the highest hazard index (results not shown). If an inert element (i.e. $\mathrm{Si}$ ) is added to calculate the $\mathrm{EC}_{50}$ of the mixture, the Hls are still higher..

For HP 14 chronic, the leachate method 2a classifies wastes as hazardous slightly less frequently than the worst case method (25 and 28 times respectively). The unclassified wastes are MSWI bottom ash (waste 45), nickel sludge (waste 87) and incinerated paper sludge (waste 88). The leachate concentration could then be applied in a second step if the worst case method is estimated unsatisfactory or not matching with what is usually considered for this type of waste. It is to be noted that hazard assessment by using only the leachable concentration (method 2b) does not classify any waste for HP 14 acute nor chronic.

The elements triggering the classification by methods 1 and $2 \mathrm{a}$ are (hazard index contribution > 0.1): $\mathrm{Zn}$ (13 times), $\mathrm{Cu}$ (10), $\mathrm{Cr}$ (3), Ni (2), $\mathrm{Co}$ (1) and $\mathrm{Hg}$ (1). 
Classification with $\mathrm{M}=1$ :

- for Method 1 (worst case using only total content), 3 waste are classified as hazardous instead of 12 when $M$ factors are used;

- for Method 2a (hazard statement code by leachate concentration, and waste classification by total content), 2 wastes are classified as hazardous instead of 10 when $\mathrm{M}$ factors are used.

The conclusion is that the use of $M$ factor set to 1 for all substances is not sufficiently discriminating between hazardous and non-hazardous materials. It seems that the proposal of DG Env to use only the M factors that are in the CLP tables should be improved.

\section{CONCLUSIONS}

The classification according to the proposed methods is comparable to the LoW classification for the 45 wastes with exhaustive elemental and organic analytical data and flammability test available. No match is however observed in case of partial assessment (partial ecotoxicity battery - without terrestrial tests, or partial composition data - without organic compounds). Therefore partial assessment should be avoided.

HP 14 is the most frequent criterion that classifies a waste as hazardous due mostly to metal concentration. Thus, the new definition of HP 14 within the new framework directive will have an impact on the number of mirror entries that will be classified as hazardous based on their metal concentrations.

For all solid wastes the HP14 criteria are more discriminating for classification as hazardous relative to other HPs. Only in the category of solvents HP3 is the more relevant criterion. For the already wide range of wastes studied, acute ecotoxicity has been shown to be never decisive in declaring a waste hazardous. It is always the chronic ecotoxicity, which is more discriminating.

Hazard classification based on calculation with the total concentrations and worst case M-factors for the metals leads probably to an overestimation of the hazard and unnecessary classification of some waste as hazardous. The leachate approach proposed here is slightly less severe. Information on the metal speciation is therefore needed for a realistic hazard assessment.

Within the classification based on HP14 the elements $\mathrm{Zn}, \mathrm{Pb}$ and $\mathrm{Cu}$ are most often determining classification as hazardous (when considering only inorganic substances). Progress in the speciation of specifically $\mathrm{Zn}$ and $\mathrm{Cu}$ are essential for HP 14. $\mathrm{Pb}$ has a "generic entry" in the CLP, and speciation is not necessary. Progress in the speciation of $\mathrm{Zn}$, Co and $\mathrm{Ni}$ are important for human toxicity . Chromium(VI) must be measured by the corresponding standard. For ecotoxicity, the leachate approach proposed here should be further developed and verified with ecotoxicological testing.

The use of $\mathrm{M}$ factor set to 1 for all substances is not sufficiently discriminating between hazardous and non-hazardous materials. 
For HP14 metals seem to be the most determining classifiers. For some other hazard properties organic substances are the main classifiers. For full assessment information on all types of substances and all physicochemical properties are needed.

\section{REFERENCES}

AFNOR XP X30-489 (2013): Characterization of waste - Determination of the content of elements and substances in waste. AFNOR, Saint Denis La Plaine, France.

CLP Regulation 2008. Classification, Labelling and Packaging of Substances and Mixtures Regulation $\quad$ (CLP). 1350 pp. http://ec.europa.eu/enterprise/sectors/chemicals/documents/classification

Deprez K, Robbens J, Nobels I, Vanparys C, Vanermen G, Tirez K, Michiels L, Weltens R. 2012. DISCRISET: A battery of tests for fast waste classification Application of tests. on waste extracts. Waste Management 32 (2012) 22182228

DG ENV 2012a. "Unofficial Draft of amending Directive 2008/98/EC /EC as regards Annex III". EU, November 2012.

DG ENV 2012b. "Commission Decision of XXX amending Decision 2000/532/EC Unofficial Draft", EU, November 2012.

EN 12457-2 (2002). Characterization of waste - Leaching - Compliance test for leachaing of granular waste materials and sludges - Part 2: One stage batch test at a liquid to solid ratio of $10 \mathrm{l} / \mathrm{kg}$ for materials with a particle size below 4 $\mathrm{mm}$ (with or without particle size reduction).

EN 14735 (2006). Characterization of waste - Preparation of waste samples for ecotoxicity tests, CEN, Brussels, Belgium.

EN 15192 (2007). Characterisation of waste and soil - Determination of chromium (VI) in solid material by alkaline digestion and ion chromatography with spectrophotometric detection

EU 2000. List of Wastes Decision 2000/532/EC. Commission decision of 3 May 2000 replacing Decision 94/3/EC establishing a list of wastes pursuant to Article 1(a) of Council Directive 75/442/EEC on waste and Council Decision 94/904/EC establishing a list of hazardous waste pursuant to Article 1(4) of Council Directive 91/689/EEC on hazardous waste Commission Decision 2000/532/EC, as amended by 2001/118/EC, 2001/119/EC and 2001/573/EC. http://eurlex.europa.eu/LexUriServ/site/en/consleg/2000/D/02000D0532-20020101en.pdf (consolidated version).

EU 2003. Council Decision 2003/33/EC of 19 December 2002 establishing criteria and procedures for the acceptance of waste at landfills pursuant to Article 16 of and Annex II to Directive 1999/31/EC. Official Journal of the European Communities. L11/27. 16.1.2003.

EU 2008. Waste Framework Directive 2008/98/EC. Directive 2008/98/EC of the European parliament and of the council of 19 November 2008 on waste and repealing certain Directives. http://eurlex.europa.eu/LexUriServ/LexUriServ.do?uri=CELEX:32008L0098:EN:NOT 
Garcia Burgués J. 2013. Amendment of the waste classification system. European Commission, DG Environment. Brussels, 21 March 2013. 8 pp.

Hennebert P, Papin A, Padox J-M, Hazebrouck B. 2013a. The evaluation of an analytical protocol for the determination of substances in waste for hazard classification. Waste Management 33 (2013) 1577-1588.

Hennebert P, Rebischung F, Langeron P. 2013b. EU waste hazardousness assessement - Proposition of methods. Sardinia $201314^{\text {th }}$ international waste management and landfill symposium.

Hennebert P, Rebischung F, Langeron P. 2013c. EU waste hazardousness assessment - Proposition of methods. Proceedings Sardinia 2013, Fourteenth International Waste Management and Landfill Symposium, S. Margharita di Pula, Cagliari, Italia. Published by CISA, Italy.

Hennebert P, Rebischung F. 2013. Waste Hazardousness Assessment - Proposition of methods. Report INERIS- DRC-13-136159-04172A- 69 pp. http://www.ineris.fr/centredoc/drc-13-136159-04172a-hazardous-wasteassessment-vf3-1379929842.pdf

Hjelmar, O., van der Sloot, H.A., van Zomeren, A. 2013. Hazard property classification of high temperature waste materials. Proceedings Sardinia 2013, Fourteenth International Waste Management and Landfill Symposium, S. Margharita di Pula, Cagliari, Italia. Published by CISA, Italy.

Pandard P and Römbke J. 2013. Proposal for a "Harmonized" Strategy for the Assessment of the HP 14 Property. Integrated Environmental Assessment and Management. DOI 10.1002/ieam.1447

Postma J.F., van der Sloot, H.A. and van Zomeren A. Ecotoxicological response of three waste samples in relation to chemical speciation modelling of leachates. In : Ecotoxicological characterization of waste - Results and experiences from a European ring test. Eds: J. Römbke, R. Becker \& H. Moser, Springer Science+Business Media, Inc. Norwell (MA), 2009.

PrEN 14405 (2004).: Characterization of waste - Leaching behaviour tests - Up-flow percolation test (under specified conditions)., CEN, Brussels, Belgium.

PrEN 14429 (2005). Characterization of waste - Leaching behaviour tests - Influence of $\mathrm{pH}$ on leaching with initial acid/base addition., CEN, Brussels, Belgium.

PrEN 14997 (2006). Characterization of waste - Leaching behaviour tests Influence of $\mathrm{pH}$ on leaching with continuous $\mathrm{pH}$-control. CEN, Brussels, Belgium.

van der Sloot Consultancy, DHI, ECN. 2013. HP classification of European incinerator bottom ash (IBA). Part 1: Compilation of data on IBA composition and leaching properties. January 2013. 39 pp. Part 2: Assessment of hazardous properties (HPs) of IBA. January 2013. 61 pp.

van der Sloot, H.A., Seignette, P.F.A.B., Meeussen, J.C.L., Hjelmar, O. and Kosson, D.S. 2008. A database, speciation modelling and decision support tool for soil, sludge, sediments, wastes and construction products: LeachXSTM_ Orchestra. In: Second international symposium on energy from biomass and waste, Venice 2008. 
Weltens R, Vanermen G, Tirez K, Robbens J, Deprez K, Michiels L. 2012. Screening tests for hazard classification of complex waste materials - Selection of methods. Waste Management 32 (2012) 2208-2217. 


\section{SUPPLEMENTARY INFORMATION}

Table 9.1: List of properties that render a waste hazardous.

\begin{tabular}{|c|c|}
\hline HP code & Hazardous property \\
\hline HP 1 & $\begin{array}{l}\text { Explosive: Wastes which are capable by reaction or producing gas at such a } \\
\text { temperature and pressure and at such a speed as to cause damage to the surroundings. } \\
\text { Pyrotechnic wastes, explosive organic peroxide wastes and explosive self-reactive } \\
\text { wastes are included. }\end{array}$ \\
\hline HP 2 & $\begin{array}{l}\text { Oxidising: Wastes which may, generally by providing oxygen, cause or contribute to the } \\
\text { combustion of other materials. }\end{array}$ \\
\hline HP 3 & $\begin{array}{l}\text { Flammable: } \\
\text { - flammable liquid wastes: liquid wastes having a flash point below } 60^{\circ} \mathrm{C} \text { or waste gas } \\
\text { oil, diesel and light heating oils having a flash point }>50^{\circ} \mathrm{C} \text { and } \leq 75^{\circ} \mathrm{C} \text {; } \\
\text { flammable pyrophoric liquid and solid wastes: solid or liquid wastes which, even } \\
\text { in small quantities, are liable to ignite within five minutes after coming into contact with } \\
\text { air; } \\
\text { flammable solid wastes: solid wastes which are readily combustible or may cause } \\
\text { or contribute to fire through friction; } \\
\text { flammable gaseous wastes: gaseous wastes which are flammable in air at } 20^{\circ} \mathrm{C} \text { and } \\
\text { a standard pressure of } 101.3 \mathrm{kPa} \text {; } \\
\text { water reactive wastes: wastes which, in contact with water, emit flammable gases in } \\
\text { dangerous quantities; } \\
\text { other flammable wastes: flammable aerosols, flammable self-heating wastes, } \\
\text { flammable organic peroxides and flammable self-reactive wastes. }\end{array}$ \\
\hline HP 4 & $\begin{array}{l}\text { Irritant: } \\
\text { Skin irritant and eye damage: Wastes which on application can cause skin irritation or } \\
\text { damage to the eye. }\end{array}$ \\
\hline HP 5 & $\begin{array}{l}\text { Single target organ toxicity (STOT)/Aspiration: } \\
\text { Specific target organ toxicity (STOT)/Aspiration: Wastes which can cause specific } \\
\text { target organ toxicity either from a single or repeated exposure, or which cause severe } \\
\text { acute toxic effects following aspiration. }\end{array}$ \\
\hline HP 6 & $\begin{array}{l}\text { Acute toxicity: Wastes that can cause acute toxic effects following oral or dermal } \\
\text { administration or inhalation exposure. }\end{array}$ \\
\hline HP 7 & Carcinogenic: Wastes which induce cancer or increases its incidence. \\
\hline HP 8 & Corrosive: Wastes which on application can cause skin corrosion. \\
\hline HP 9 & $\begin{array}{l}\text { Infectious: Waste containing viable micro-organisms or their toxins which are known or } \\
\text { reliably believed to cause disease in man or other living organisms. }\end{array}$ \\
\hline HP 10 & $\begin{array}{l}\text { Toxic for reproduction: Wastes which have adverse effects on sexual function and } \\
\text { fertility in adult males and females, as well as developmental toxicity in the offspring.. }\end{array}$ \\
\hline HP 11 & $\begin{array}{l}\text { Mutagenic: Wastes which may cause a mutation, that is a permanent change in the } \\
\text { amount or structure of genetic material in a cell. }\end{array}$ \\
\hline HP 12 & $\begin{array}{l}\text { Release of an acute toxic gas cat. 1, } 2 \text { or } 3 \text { : Wastes which release toxic gases cat. 1, } 2 \\
\text { or } 3 \text { in contact with water or an acid. }\end{array}$ \\
\hline HP 13 & $\begin{array}{l}\text { Sensitising: Wastes which contain one or more substances known to cause sensitising } \\
\text { effects to the skin or the respiratory organs. }\end{array}$ \\
\hline HP 14 & $\begin{array}{l}\text { Ecotoxic: Wastes which present or may present immediate or delayed risks for one or } \\
\text { more sectors of the environment. }\end{array}$ \\
\hline HP 15 & $\begin{array}{l}\text { Yielding another substance: Waste capable of exhibiting a hazardous property listed } \\
\text { above not directly displayed by the original waste. }\end{array}$ \\
\hline
\end{tabular}


Table 9.2: Overview of HPs and associated HSCs.

\begin{tabular}{|c|c|c|c|c|c|}
\hline HP & Hazard Class and Category & HSC & HP & Hazard Class and Category & HSC \\
\hline \multirow[t]{11}{*}{ HP1 } & Explosive & & HP 7 & Carcinogenic & \\
\hline & Unstable explosive & H 200 & & Carcinogenic $1 \mathrm{~A}$ & H 350 \\
\hline & Expl. 1.1; mass explosion hazard & H 201 & & Carcinogenic 1B & H 350 \\
\hline & Expl. 1.2; severe projection hazard & H 202 & & Carcinogenic 2 & H 351 \\
\hline & Expl. 1.3; fire, blast or projection hazard & $\mathrm{H} 203$ & & & \\
\hline & Expl. 1.4; fire or projection hazard & $\mathrm{H} 204$ & HP 8 & Corrosive & \\
\hline & Self-reactive, type $A$ & \multirow{2}{*}{$\mathrm{H} 240$} & & Skin corrosive $1 \mathrm{~A}$ & H 314 \\
\hline & Organic peroxides, type A & & & Skin corrosive $1 \mathrm{~B}$ & H 314 \\
\hline & Self-reactive, type B & \multirow{2}{*}{$\mathrm{H} 241$} & & Skin corrosive $1 \mathrm{C}$ & H 314 \\
\hline & Organic peroxides, type B & & & & \\
\hline & & & HP 9 & Infectious & None \\
\hline \multirow[t]{7}{*}{ HP2 } & Oxidising & & & & \\
\hline & Oxidising gas 1 & $\mathrm{H} 270$ & HP 10 & Toxic for reproduction & \\
\hline & Oxidising liquid 1 & \multirow{2}{*}{ H 271} & & Reproduction $1 \mathrm{~A}$ & H 360 \\
\hline & Oxidising solid 1 & & & Reproduction 1B & H 360 \\
\hline & Oxidising liq. 2, Oxidising liq. 3 & \multirow{2}{*}{ H 272} & & Reproduction 2 & H 361 \\
\hline & Oxidising sol. 2, Oxidising sol. 3 & & & & \\
\hline & & & HP 11 & Mutagenic & \\
\hline \multirow[t]{16}{*}{ HP3 } & Flammable & & & Mutagenic $1 \mathrm{~A}$ & $\mathrm{H} 340$ \\
\hline & Flammable gas 1 & $\mathrm{H} 220$ & & Mutagenic 1B & H 340 \\
\hline & Flammable gas 2 & $\mathrm{H} 221$ & & Mutagenic 2 & H 341 \\
\hline & Flammable aerosol 1 & $\mathrm{H} 222$ & & & \\
\hline & Flammable aerosol 2 & $\mathrm{H} 223$ & HP 12 & Release of an acute toxic gas & \\
\hline & Flammable liquid 1 & $\mathrm{H} 224$ & & Contact w. water lib. tox gas & EUH029 \\
\hline & Flammable liquid 2 & $\mathrm{H} 225$ & & Contact w. acid lib. tox gas & EUH031 \\
\hline & Flammable liquid 3 & $\mathrm{H} 226$ & & Cont. w. acid lib. very tox gas & EUH032 \\
\hline & Flam. solid 1, Flam. solid 2 & $\mathrm{H} 228$ & & & \\
\hline & $\begin{array}{l}\text { Self-react. subst. and mix., type } C \text { and } D \\
\text { Self-react. subst. and mix., type } E \text { and } F \\
\text { Organic peroxides, type } C \text { and } D \\
\text { Organic peroxides, type } E \text { and } F\end{array}$ & H 242 & & & \\
\hline & Pyrophoric liq. 1 and pyrophoric solid 1 & $\mathrm{H} 250$ & HP 13 & Sensitising & \\
\hline & Self-heating subst. and mixtures, type 1 & $\mathrm{H} 251$ & & Causes allergic skin reaction & H 317 \\
\hline & Self-heating subst. and mixtures, type 2 & H 252 & & $\begin{array}{l}\text { May cause allergy, asthma or } \\
\text { breathing difficulties if inhaled }\end{array}$ & H 334 \\
\hline & Water-reactive subst. and mixt., type 1 & $\mathrm{H} 260$ & & & \\
\hline & Water-reactive subst. and mixt., type 2 and 3 & $\mathrm{H} 261$ & HP 14 & Ecotoxic & \\
\hline & & & & Aquatic acute 1 & $\mathrm{H} 400$ \\
\hline HP 4 & Irritant (skin and eye) & & & Aquatic chronic 1 & H 410 \\
\hline
\end{tabular}




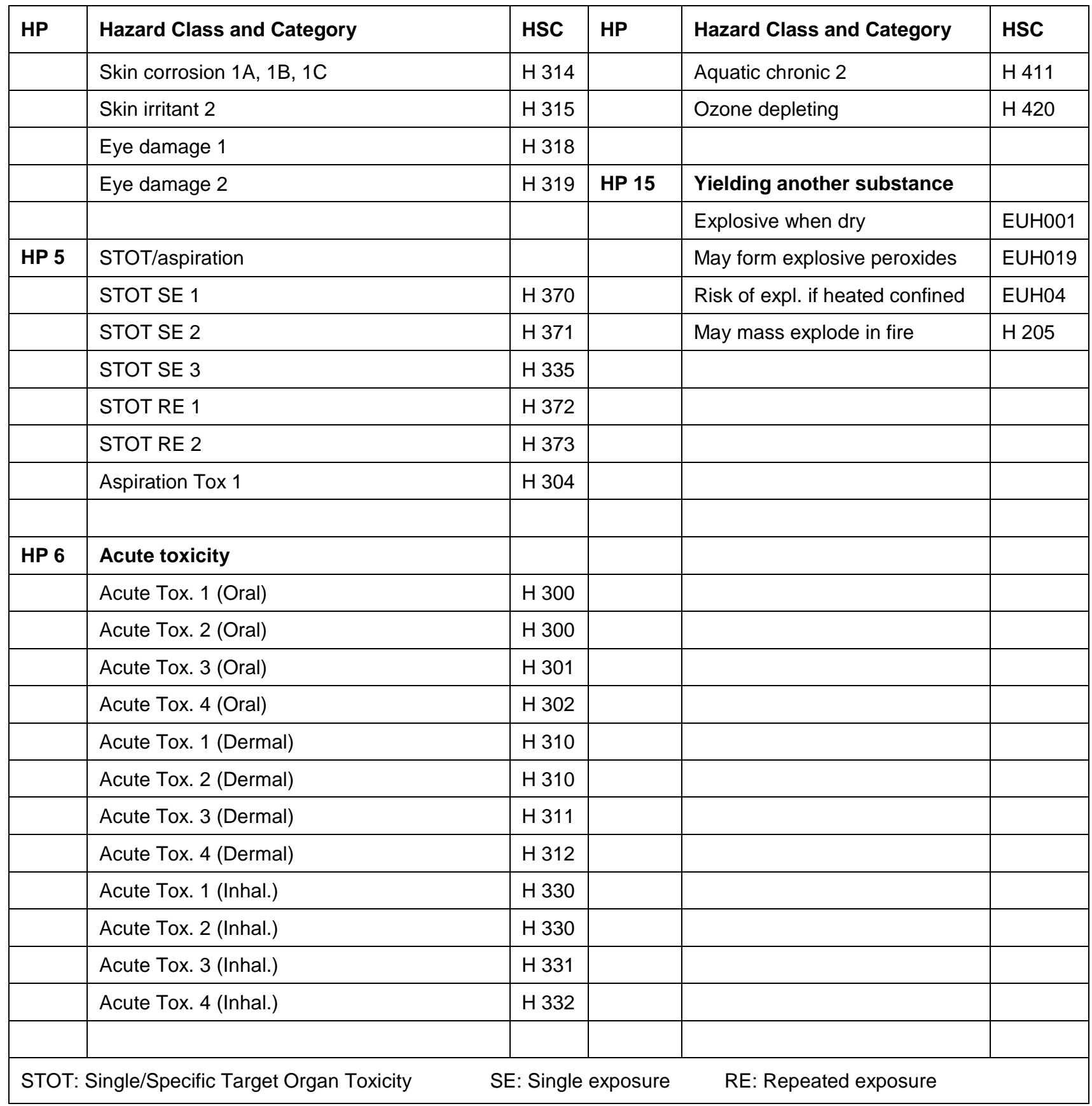

Ecotoxicological tests of DS 3

\begin{tabular}{|l|l|c|c|c|}
\hline \multicolumn{1}{|c|}{ LoW code } & Waste & $\begin{array}{c}\text { EC50, 30 min } \\
\text { (leachate \%) } \boldsymbol{\mu t o x}\end{array}$ & $\begin{array}{c}\text { EC50, 72h } \\
\text { (leachate \%) algae }\end{array}$ & $\begin{array}{c}\text { EC50, 48u } \\
\text { (leachate \%) } \\
\text { daphnia }\end{array}$ \\
\hline $190111^{*}$ & Bottom ashes & 15 & $<6$ & $<6$ \\
\hline $190115^{*}$ & Boiler ashes & 21 & $<6$ & $>15$ \\
\hline $191206^{*}$ or 191207 & Carpentry pellets & 34 & $<6$ & $<6$ \\
\hline $190813^{*}$ & Sludge & $>100$ & $<6$ & 18 \\
\hline $190113^{*}$ & Fly ashes & $>100$ & 8 & $>$ \\
\hline $191005^{*}$ & Shredder residue & $>100$ & 8 & 25 \\
\hline $191005^{*}$ & Shredder residue & 26 & 19 & 75 \\
\hline $170503^{*}$ & Soil contaminated & 62 & 29 & 75 \\
\hline $170503^{*}$ & Soil contaminated & 44 & & $<$ \\
\hline
\end{tabular}




\begin{tabular}{|c|c|c|c|c|}
\hline $190813^{*}$ & Sludge & 60 & 74 & 54 \\
\hline $190117^{*}$ & Ashes & $>100$ & 34 & 22 \\
\hline $170503^{*}$ & Soil contaminated & $>100$ & 42 & $>100$ \\
\hline $170903^{*}$ & $\begin{array}{l}\text { Construction \& } \\
\text { demolition waste }\end{array}$ & $>100$ & $>100$ & $>100$ \\
\hline $190813^{*}$ & Sludge & $>100$ & $>100$ & $>100$ \\
\hline $190115^{*}$ or 190116 & Filter cake inc. & $>100$ & $>100$ & $>100$ \\
\hline $\begin{array}{l}190113^{*} \text { or } 190114 \text { and } \\
190115^{*} \text { or } 190116\end{array}$ & Ashes inc. & $>100$ & $>100$ & $>100$ \\
\hline $190205^{*}$ or 190206 & Filter cake WWT & $>100$ & $>100$ & $>100$ \\
\hline
\end{tabular}


Classification of waste of DS1 for the different rules of each HP (figures are hazard index)

\begin{tabular}{|c|c|c|c|c|c|c|c|c|c|c|c|c|c|c|c|c|c|c|c|c|c|c|c|c|}
\hline HP rule & \begin{tabular}{|l|}
$\mathrm{HP}$ \\
$4 \mathrm{~A}$ \\
\end{tabular} & \begin{tabular}{|l|}
$\mathrm{HP}$ \\
$4 \mathrm{~B}$ \\
\end{tabular} & \begin{tabular}{|l|}
$\mathrm{HP}$ \\
$4 \mathrm{C}$ \\
\end{tabular} & \begin{tabular}{|l|}
$\mathrm{HP}$ \\
$5 \mathrm{~A}$ \\
\end{tabular} & $\begin{array}{l}\mathrm{HP} \\
5 \mathrm{~B}\end{array}$ & $\begin{array}{l}\mathrm{HP} \\
5 \mathrm{C} \\
\end{array}$ & \begin{tabular}{|l|l|}
$\mathrm{HP}$ \\
$5 \mathrm{D}$ \\
\end{tabular} & \begin{tabular}{|l|}
$\mathrm{HP}$ \\
$5 \mathrm{E}$ \\
\end{tabular} & \begin{tabular}{|l|}
$\mathrm{HP}$ \\
$6 \mathrm{~A}$ \\
\end{tabular} & \begin{tabular}{|l|}
$\mathrm{HP}$ \\
$6 \mathrm{~B}$ \\
\end{tabular} & \begin{tabular}{|l|}
$\mathrm{HP}$ \\
$6 \mathrm{C}$ \\
\end{tabular} & $\begin{array}{l}\mathrm{HP} \\
7 \mathrm{~A} \\
\end{array}$ & $\begin{array}{l}\mathrm{HP} \\
7 \mathrm{~B} \\
\end{array}$ & \begin{tabular}{l|l|}
$\mathrm{HP}$ \\
$8 \mathrm{~A}$ \\
\end{tabular} & \begin{tabular}{l|l|}
$\mathrm{HP}$ \\
$10 \mathrm{~A}$
\end{tabular} & \begin{tabular}{|l|}
$\mathrm{HP}$ \\
$10 \mathrm{~B}$ \\
\end{tabular} & \begin{tabular}{|l|}
$\mathrm{HP}$ \\
$11 \mathrm{~A}$ \\
\end{tabular} & \begin{tabular}{|l|}
$\mathrm{HP}$ \\
$11 \mathrm{~B}$ \\
\end{tabular} & \begin{tabular}{|l|}
$\mathrm{HP}$ \\
$13 \mathrm{~A}$ \\
\end{tabular} & \begin{tabular}{|l|}
$\mathrm{HP}$ \\
$13 \mathrm{~B}$ \\
\end{tabular} & \begin{tabular}{|l|}
$\mathrm{HP}$ \\
$14 \mathrm{~A}$ \\
\end{tabular} & \begin{tabular}{|l|}
$\mathrm{HP}$ \\
$14 \mathrm{~B}$ \\
\end{tabular} & Hazard Index & $\mathrm{Nb}$ rules $\mathrm{HI}$ \\
\hline 1 & 0.89 & 0.11 & \begin{tabular}{|l|l|}
0.05 \\
\end{tabular} & 0.04 & 0 & 0.03 & \begin{tabular}{|l|}
0.03 \\
\end{tabular} & 0 & \begin{tabular}{|l|}
0.05 \\
\end{tabular} & \begin{tabular}{|l|l|} 
\\
\end{tabular} & \begin{tabular}{|l|}
0.01 \\
\end{tabular} & 0.3 & 0.01 & 0.18 & 0.1 & 0 & 0 & 0.03 & 0 & 0 & \begin{tabular}{|l|}
0.03 \\
\end{tabular} & \begin{tabular}{|l|}
0.09 \\
\end{tabular} & 0.89 & 0 \\
\hline 2 & 0 & 0.01 & 0.12 & 0 & 0 & 0.03 & 0.01 & 0.01 & 0.11 & 0 & 0.01 & 0.05 & 0.01 & 0 & 0.02 & 0 & 0 & 0.01 & 0 & 0 & 0.06 & $\mid 0.19$ & 0.19 & 0 \\
\hline 3 & 0 & 0.07 & 0.07 & 0.02 & 0 & 0.02 & 0.09 & 0.03 & 0.1 & 0.03 & 0.04 & 1.38 & 0.03 & 0.07 & 0.46 & 0.01 & 0.01 & 0.14 & 0.01 & 0.01 & 0.23 & 1.27 & 1.38 & 2 \\
\hline 4 & 0 & 0.01 & 0.11 & 0 & 0 & 0 & 0.01 & 0.01 & 0.1 & 0 & 0.01 & 0.07 & 0.01 & 0 & 0.04 & 0 & 0 & 0.01 & 0 & 0 & 0.04 & 0.33 & 0.33 & 0 \\
\hline 5 & 0 & 0.12 & 0.13 & 0.03 & 0 & 0.03 & 0.06 & 0.01 & 0.13 & 0.05 & 0.02 & 0.57 & 0.02 & 0.14 & 0.19 & 0 & 0 & 0.06 & 0.01 & 0 & 0.27 & 0.83 & 0.83 & 0 \\
\hline 6 & 0 & 0.21 & 0.07 & 0 & 0 & 0.06 & 0 & 0 & 0.08 & 0.09 & 0 & 0.04 & 0 & 0.28 & 0.01 & 0 & 0 & 0 & 0 & 0 & 0.05 & 0 & 0.28 & 0 \\
\hline 7 & 0 & 0 & 0 & 0 & 0 & 0 & 0 & 0 & 0 & 0 & 0 & 0 & 0 & 0 & 0 & 0 & 0 & 0 & 0 & 0 & 0 & 0 & 0.00 & 0 \\
\hline 8 & 0 & 0.05 & 0.27 & 0 & 0 & 0 & $\mid 0.02$ & 0.01 & 0.24 & 0 & 0.02 & 0.11 & 0 & 0 & 0.04 & 0.01 & 0 & 0.02 & 0 & 0 & 0.05 & $\mid 0.29$ & 0.29 & 0 \\
\hline 9 & 0 & 0.37 & 0.27 & 0 & 0 & 0 & 0.01 & 0 & 0.15 & 0 & 0.01 & 0.09 & 0 & 0.01 & 0.03 & 0 & 0 & 0.01 & 0 & 0 & 0 & 0.05 & 0.37 & 0 \\
\hline 10 & 0 & 0.1 & 0.14 & 0.01 & 0 & 0.01 & 0.06 & 0.02 & 0.11 & 0 & 0.01 & 0.65 & 0.02 & 0 & 0.22 & 0 & 0.01 & 0.06 & 0.01 & 0.01 & 0.04 & 1.13 & 1.13 & 1 \\
\hline 11 & 0 & 0.85 & | 3.73 & 0 & 0 & 0 & 0.02 & 0.02 & 0.36 & 0.01 & 0.07 & 0 & 0.19 & 0.32 & 0.59 & 0 & 0.2 & 0.01 & 0 & 0 & 1.01 & | $9.84 \mid$ & 9.84 & 3 \\
\hline 12 & 0 & 0.77 & 2.38 & 0 & 0 & 0 & 0.02 & 0.01 & 0.35 & 0 & 0.06 & 0.72 & 0.07 & 0.31 & 0.23 & 0 & 0.16 & 0.01 & 0 & 0 & 0.8 & 7.92 & 7.92 & 2 \\
\hline 13 & 0 & 1.18 & 2.7 & 0 & 0 & 0 & 0.03 & 0.03 & 0.59 & 0 & 0.11 & 0 & 0.36 & 0.82 & 1.14 & 0.01 & 0.34 & 0.02 & 0 & 0 & 2.02 & 20.5 & 20.49 & 5 \\
\hline 14 & 0 & 0.28 & 0.96 & 0 & 0 & 0 & 0.04 & 0.1 & 0.41 & 0.03 & 0.14 & 0.72 & 1.02 & 0.67 & 3.22 & 0 & 0.22 & 0.05 & 0 & 0 & 2.38 & $\mid 16.9$ & 16.94 & 4 \\
\hline 15 & 0 & 0.19 & $\mid 0.47$ & 0 & 0 & 0 & 0.06 & 0.09 & 0.35 & 0.02 & 0.14 & 0.72 & 0.99 & 0.62 & 3.14 & 0 & 0.21 & 0.06 & 0.01 & 0 & 2.41 & $\mid 13.8$ & 13.84 & 3 \\
\hline 16 & 0 & 0.31 & 0.66 & 0 & 0 & 0 & 0.3 & 0.24 & $\mid 0.89$ & 0 & 0.34 & 1.16 & 0.1 & 1.05 & 1.01 & 0.01 & 0.28 & 0.3 & 0.03 & 0.03 & 4.8 & $\mid 19.5$ & 19.50 & 5 \\
\hline 17 & 0.01 & 0.19 & 2.62 & 0 & 0 & 0.06 & 0.01 & 0.01 & 0.14 & 0.08 & 0.05 & 0 & 0.03 & 0.26 & 0.1 & 0 & 0.1 & 0 & 0 & 0 & 0.14 & 0.35 & 2.62 & 1 \\
\hline 18 & 0.04 & 0.18 & 0.23 & 0.1 & 0 & 0.05 & 0.06 & 0.01 & 0.25 & 0.08 & 0.19 & 0 & 0.05 & 0.33 & 0.2 & 0.01 & 0.61 & 0.03 & 0.01 & 0.01 & 0.4 & 2.88 & 2.88 & 1 \\
\hline 19 & 0.03 & 0.12 & 0.17 & 0.1 & 0 & 0.02 & 0.05 & 0.01 & 0.28 & 0.04 & 0.17 & 0 & 0.03 & 0.31 & 0.15 & 0.04 & 0.46 & 0.02 & 0 & 0 & 30.9 & $\mid 278$ & 278.46 & 2 \\
\hline 20 & 0.12 & 0.17 & 0.3 & 0.1 & 0 & 0.04 & $\mid 0.18$ & 0.01 & 0.33 & 0.06 & 0.44 & | 39.9 & 0.03 & 0.29 & 0.59 & 0.04 & 1.78 & 0.1 & 0.02 & 0.02 & 0.58 & 5.54 & 39.86 & 3 \\
\hline 21 & 0.06 & 0.1 & $\mid 0.14$ & 0.1 & 0 & 0.03 & $\mid 0.09$ & 0 & 0.17 & 0.04 & 0.23 & 0.8 & 0.02 & 0.16 & 0.29 & 0.02 & 0.87 & 0.02 & 0.01 & 0.01 & 0.3 & 2.05 & 2.05 & 1 \\
\hline 22 & 0.03 & 0.82 & $|0.37|$ & 0.1 & 0 & 0.12 & 0.05 & 0.05 & 0.39 & 0.16 & 0.16 & 0 & 0 & 0.64 & 0.17 & 0.01 & 0.51 & 0.01 & $\mid$\begin{tabular}{|l|l}
$\mid$ \\
$\mid$
\end{tabular} & 0.01 & 0.71 & | 4.49 & 4.49 & 1 \\
\hline
\end{tabular}




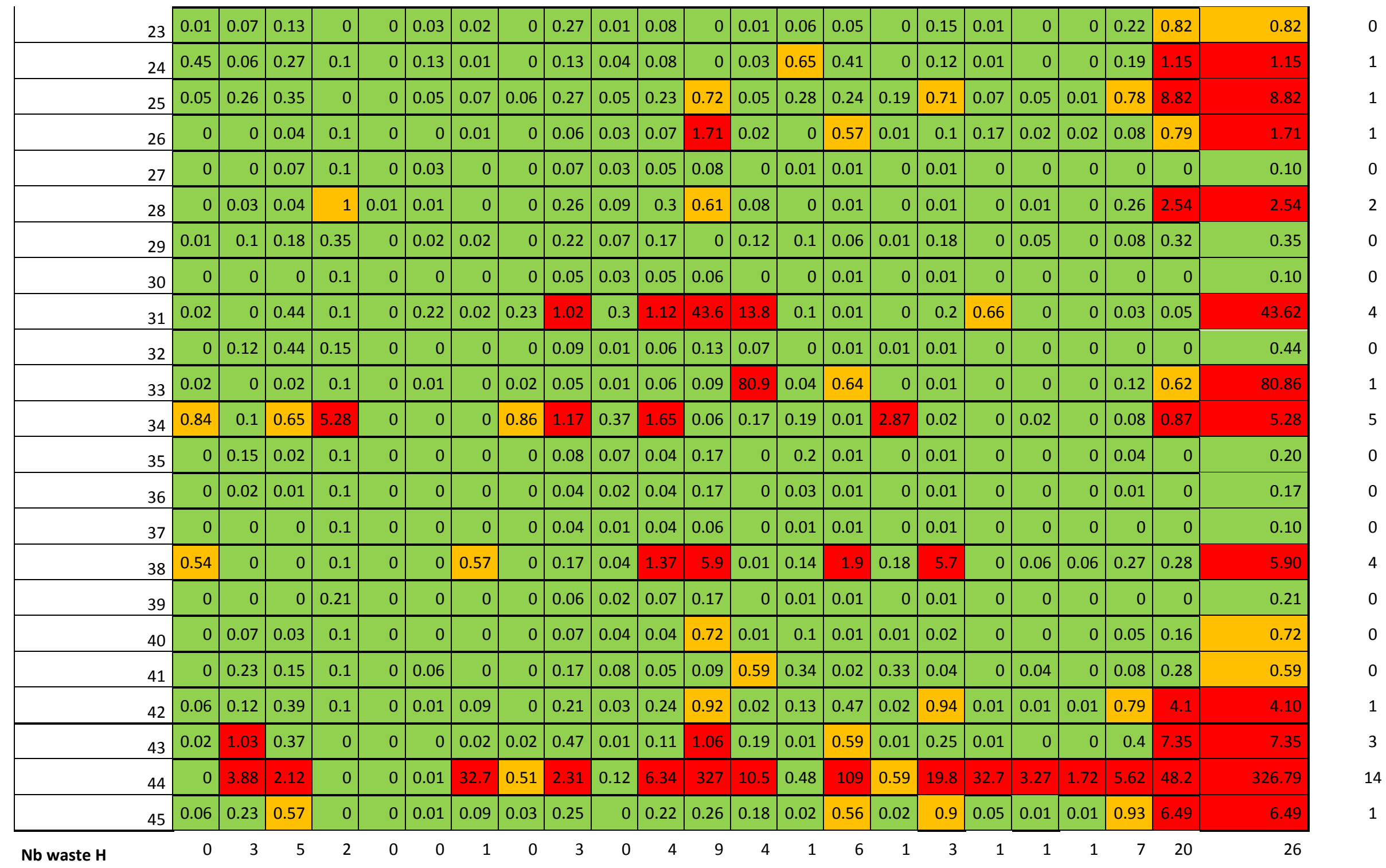

Page $39 / 51$ 
Classification by different methods for HP 14

\section{DS1}

26 solid samples have been classified according to the methods proposed for HP 14 , using the cut-off values.

For HP 14 acute,

\begin{tabular}{|c|c|c|c|}
\hline Sample code 1 & Worst case Hazard Index & EC50 of mixtures Hazard Index & Leachate concentration Hazard Index \\
\hline 2 & 0.02 & 3.60 & 0.01 \\
\hline 3 & 0.12 & 0.16 & 0.10 \\
\hline 4 & 0.01 & 0.03 & 0.01 \\
\hline 5 & 0.02 & 0.04 & 0.02 \\
\hline 10 & 0.06 & 0.08 & 0.04 \\
\hline 11 & 0.52 & 0.39 & 0.34 \\
\hline 12 & 0.36 & 0.35 & 0.31 \\
\hline 13 & 0.93 & 0.94 & 0.83 \\
\hline 14 & 1.19 & 1.01 & 1.11 \\
\hline 17 & 0.02 & 0.03 & 0.00 \\
\hline 19 & 0.64 & 0.76 & 0.64 \\
\hline 21 & 0.09 & 0.11 & 0.09 \\
\hline 23 & 0.02 & 0.07 & 0.01 \\
\hline 24 & 0.28 & 0.31 & 0.28 \\
\hline 25 & 1.06 & 1.16 & 0.98 \\
\hline 42 & 0.29 & 0.31 & 0.25 \\
\hline 44 & 9.19 & 13.52 & 0.63 \\
\hline 45 & 0.36 & 0.42 & 0.07 \\
\hline 46 & 0.01 & 0.04 & 0.01 \\
\hline 47 & 0.15 & 0.16 & 0.11 \\
\hline $16 S 6$ & 1.27 & 1.62 & 0.25 \\
\hline $16 \mathrm{~S} 6.2$ & 1.60 & 2.47 & 0.39 \\
\hline 48 & 0.02 & 0.03 & 0.01 \\
\hline 49 & 0.04 & 0.04 & 0.03 \\
\hline 50 & 0.12 & 0.13 & 0.09 \\
\hline 51 & 0.20 & 0.13 & 0.11 \\
\hline Mean HI & 0.71 & 1.07 & 0.26 \\
\hline $\mathrm{Nb} \mathrm{H}$ & 5 & 6 & 1 \\
\hline Total & 26 & & \\
\hline
\end{tabular}

\section{For $\mathrm{PH} 14$ chronic}

\begin{tabular}{|r|r|r|r|}
\hline Sample code 1 & Worst case Hazard Index & Leachate concentration Hazard Index & Elements triggering classification \\
\hline 2 & 0.16 & 0.16 & \\
\hline
\end{tabular}




\begin{tabular}{|c|c|c|c|}
\hline 3 & 1.23 & 1.23 & $\mathrm{Cr}, \mathrm{Zn}, \mathrm{Co}$ \\
\hline 4 & 0.08 & 0.08 & \\
\hline 5 & 0.16 & 0.16 & \\
\hline 10 & 0.59 & 0.59 & \\
\hline 11 & 4.11 & 3.57 & $\mathrm{Zn}, \mathrm{Pb}$ \\
\hline 12 & 3.41 & 3.06 & $\mathrm{Zn}, \mathrm{Pb}, \mathrm{Cu}$ \\
\hline 13 & 9.18 & 8.27 & $\mathrm{Zn}, \mathrm{Pb}$ \\
\hline 14 & 9.93 & 9.41 & $\mathrm{Zn}, \mathrm{Pb}, \mathrm{Cu}, \mathrm{Hg}$ \\
\hline 17 & 0.19 & 0.00 & \\
\hline 19 & 6.39 & 6.39 & $\mathrm{Cu}, \mathrm{Zn}$ \\
\hline 21 & 0.88 & 0.88 & \\
\hline 23 & 0.19 & 0.19 & \\
\hline 24 & 2.00 & 2.00 & $\mathrm{Zn}, \mathrm{Cr}$ \\
\hline $16 S 6$ & 12.88 & 2.52 & $\mathrm{Cu}$ \\
\hline 25 & 10.22 & 10.22 & $\mathrm{Zn}, \mathrm{Cu}$ \\
\hline 42 & 2.47 & 2.47 & $\mathrm{Zn}, \mathrm{Cu}, \mathrm{Pb}$ \\
\hline 44 & 92.32 & 10.52 & $\mathrm{Ni}, \mathrm{Cr}, \mathrm{Cu}$ \\
\hline 45 & 3.54 & 0.85 & \\
\hline 46 & 0.08 & 0.08 & \\
\hline 47 & 1.45 & 1.45 & $\mathrm{Zn}, \mathrm{Cu}, \mathrm{Pb}$ \\
\hline $16 \mathrm{~S} 6.2$ & 15.83 & 15.61 & $\mathrm{Zn}, \mathrm{CU}, \mathrm{Ni}, \mathrm{Pb}$ \\
\hline 48 & 0.19 & 0.19 & \\
\hline 49 & 0.38 & 0.38 & \\
\hline 50 & 1.15 & 1.15 & $\mathrm{Zn}, \mathrm{Pb}$ \\
\hline 51 & 1.17 & 1.17 & $\mathrm{Cu}, \mathrm{Zn}, \mathrm{Pb}$ \\
\hline Mean $\mathrm{HI}$ & 6.67 & 3.06 & \\
\hline $\mathrm{Nb} \mathrm{H}$ & 16 & 15 & \\
\hline Total & 26 & & \\
\hline
\end{tabular}

\section{DS4}

For HP 14 acute 15 not the 19 I provided

\begin{tabular}{|l|r|r|r|}
\hline & \multicolumn{2}{|l|}{$\begin{array}{l}\text { Worst case Hazard } \\
\text { Index }\end{array}$} & \multicolumn{2}{l|}{$\begin{array}{l}\text { EC50 of mixtures Hazard } \\
\text { Index }\end{array}$} & \multicolumn{2}{l|}{$\begin{array}{l}\text { Index } \\
\text { Sample code 1 }\end{array}$} & 0.04 & 0.14 & 0.00 \\
\hline Artificial pellets pH & 0.61 & 0.62 & 0.61 \\
\hline Cement Kiln dust & 0.02 & 0.05 & 0.02 \\
\hline $\begin{array}{l}\text { Compost from Green waste } \\
\text { TS14430 }\end{array}$ & 0.15 & 0.24 & 0.12 \\
\hline Compost from MSW EU & 0.07 & 0.11 & 0.03 \\
\hline Cont Soil Wood preservation & 0.24 & 0.31 & 0.15 \\
\hline MBA AT & 0.65 & 0.66 & 0.63 \\
\hline MSWI FA pH & 0.14 & 0.37 & 0.02 \\
\hline Nickel sludge wet & & & 0.02 \\
\hline
\end{tabular}




\begin{tabular}{|c|c|c|c|}
\hline Paper Sludge & 0.17 & 0.25 & 0.00 \\
\hline $\mathrm{Pb}$ Zn Slag & 3.75 & 4.45 & 3.75 \\
\hline Recycled Concrete Aggr & 0.00 & 0.02 & 0.00 \\
\hline Red Mud TS14429 red & 0.01 & 0.06 & 0.01 \\
\hline River sediment Rhine Harbour & 0.20 & 0.46 & 0.19 \\
\hline Sewage sludge Rural & 0.05 & 0.09 & 0.05 \\
\hline Waelz slag & 3.30 & 3.35 & 0.00 \\
\hline Mean $\mathrm{HI}$ & 0.63 & 0.75 & 0.37 \\
\hline $\mathrm{NbH}$ & 2 & 2 & 1 \\
\hline Total & 15 & & \\
\hline
\end{tabular}

\section{For HP 14 chronic}

\begin{tabular}{|c|c|c|c|}
\hline Sample code 1 & $\begin{array}{l}\text { Worst case Hazard } \\
\text { Index }\end{array}$ & $\begin{array}{l}\text { Leachate concentration Hazard } \\
\text { Index }\end{array}$ & \begin{tabular}{|l}
$\begin{array}{l}\text { Elements triggering } \\
\text { classification }\end{array}$ \\
\end{tabular} \\
\hline Artificial pellets $\mathrm{pH}$ & 0.42 & 0.06 & \\
\hline Cement Kiln dust & 6.12 & 6.12 & $Z n$ \\
\hline $\begin{array}{l}\text { Compost from Green waste } \\
\text { TS14430 }\end{array}$ & 0.17 & 0.17 & \\
\hline Compost from MSW EU & 1.52 & 1.47 & $\mathrm{Zn} \mathrm{Pb} \mathrm{Cu}$ \\
\hline Cont Soil Wood preservation & 0.75 & 0.30 & \\
\hline MBA AT & 2.43 & 1.56 & $\mathrm{~Pb} \mathrm{Cu}$ \\
\hline MSWI FA pH & 6.33 & 6.33 & Zn Cu \\
\hline Nickel sludge wet & 1.45 & 0.76 & \\
\hline Paper Sludge & 1.66 & 0.32 & \\
\hline $\mathrm{Pb}$ Zn Slag & 37.55 & 37.55 & $\mathrm{Zn} \mathrm{Pb}$ \\
\hline Recycled Concrete Aggr & 0.00 & 0.00 & \\
\hline Red Mud TS14429 red & 0.13 & 0.13 & \\
\hline River sediment Rhine Harbour & 1.95 & 1.95 & $Z n$ \\
\hline Sewage sludge Rural & 0.48 & 0.48 & \\
\hline Waelz slag & 33.03 & 4.85 & $\mathrm{~Pb}$ \\
\hline Mean $\mathrm{HI}$ & 6.27 & 4.14 & \\
\hline $\mathrm{Nb} \mathrm{H}$ & 9 & 7 & \\
\hline Total & 15 & & \\
\hline
\end{tabular}

DS5 with leachate composition data : 4 wastes

\section{HP 14 Acute}

\begin{tabular}{|l|r|r|r|r|}
\hline Sample code 1 & $\begin{array}{l}\text { Sample } \\
\text { code 2 }\end{array}$ & $\begin{array}{l}\text { Worst case } \\
\text { Hazard Index }\end{array}$ & $\begin{array}{l}\text { EC50 of mixtures } \\
\text { Hazard Index }\end{array}$ & \multicolumn{2}{l|}{$\begin{array}{l}\text { Leachate concentration } \\
\text { Hazard Index }\end{array}$} \\
\hline I Ground cleaning residue & 191301 & 0.05 & 0.21 & 0.05 \\
\hline I Shredder 1 & 191002 & 1.49 & 1.92 & 1.46 \\
\hline
\end{tabular}




\begin{tabular}{|l|r|r|r|r|}
\hline $\begin{array}{l}\text { I Sludge of industrial waste water - } \\
\text { other treament }\end{array}$ & 190814 & 1.96 & 3.88 & 1.77 \\
\hline I Soil & 170504 & 0.14 & 0.16 & 0.14 \\
\hline & & & & \\
\hline Mean HI & & 0.91 & 1.54 & 2 \\
\hline Nb H & & 2 & & \\
\hline Total & & 4 & & \\
\hline
\end{tabular}

HP 14 Chronic

\begin{tabular}{|c|c|c|c|}
\hline Sample code 1 & $\begin{array}{l}\text { Sample code } \\
2\end{array}$ & $\begin{array}{l}\text { Worst case Hazard } \\
\text { Index }\end{array}$ & $\begin{array}{l}\text { Leachate concentration Hazard } \\
\text { Index }\end{array}$ \\
\hline I Ground cleaning residue & 191301 & 0.54 & 0.54 \\
\hline I Shredder 1 & 191002 & 14.82 & 14.82 \\
\hline $\begin{array}{l}\text { I Sludge of industrial waste water - other } \\
\text { treament }\end{array}$ & 190814 & 20.00 & 19.60 \\
\hline I Soil & 170504 & 1.39 & 1.39 \\
\hline Mean $\mathrm{HI}$ & & 9.18 & 9.09 \\
\hline $\mathrm{Nb} \mathrm{H}$ & & 3 & 3 \\
\hline Total & & 4 & \\
\hline
\end{tabular}


DS5 without leachate composition data: 32 wastes

HP 14 Acute

\begin{tabular}{|c|c|c|c|}
\hline Sample code 1 & Sample code 2 & $\begin{array}{l}\text { Worst case Hazard } \\
\text { Index }\end{array}$ & \begin{tabular}{|l|} 
EC50 of mixtures \\
Hazard Index \\
\end{tabular} \\
\hline Asphalt rubble $(n=13)$ & $\begin{array}{r}170301 \text { or } \\
170302^{*}\end{array}$ & 0.00 & 0.01 \\
\hline Beton rubble $(n=13)$ & 170101 & 0.01 & 0.01 \\
\hline $\begin{array}{l}\text { Boiler ashes incineration of non hazardous waste } \\
\text { (n not known) }\end{array}$ & 190116 & 0.56 & 0.56 \\
\hline Bottom ash (n not known) & 190112 & 0.23 & 0.33 \\
\hline Bottom ashes 2 (n not known) & 190112 & 0.47 & 0.47 \\
\hline Car shredder residue $(n=10)$ & 191004 & 0.95 & 1.17 \\
\hline Domestic waste fine fraction & 200301 & 0.11 & 0.16 \\
\hline Fertilizer 1 & no code & 0.00 & 0.01 \\
\hline Fertilizer 2 & no code & 0.02 & 0.05 \\
\hline Filter cake 14 (textile WWT) & 190813 & 0.09 & 0.09 \\
\hline Filter cake 15 (paint WWT) & 190813 & 0.40 & 0.87 \\
\hline Filter cake 16 (food industry WWT) & 190813 & 0.03 & 0.04 \\
\hline Filtercake 17 (food industry WWT) & 190813 & 0.01 & 0.02 \\
\hline Filtercake 18 (food industry WWT) & 190813 & 0.01 & 0.02 \\
\hline Filtercake 19 (paint WWT) & 190813 & 0.32 & 0.45 \\
\hline Filtercake 20 (paint WWT) & 190813 & 0.32 & 0.11 \\
\hline Fly ash wood incinerator 190111 & 190114 & 0.57 & 0.64 \\
\hline Fly ashes from sludges incinerator $1(n=3)$ & 190114 & 0.21 & 0.21 \\
\hline Incineration ashes & $190114 / 12$ & 0.32 & 0.36 \\
\hline Industrial sludge $4(n=19)$ & 190812 & 0.02 & 0.03 \\
\hline Mixed rubble $(n=13)$ & 170107 & 0.01 & 0.02 \\
\hline MWWTP RWZI sludge & 190805 & 0.07 & 0.07 \\
\hline Refuse derived fuel $1(n=50)$ & 191210 & 0.05 & 0.06 \\
\hline Refuse derived fuel $2(n=500)$ & 191210 & 0.05 & 0.06 \\
\hline Shredder 2 & 191212 & 1.34 & 1.53 \\
\hline Shredder fluff & 191212 & 0.82 & 0.86 \\
\hline Sieved sand $(n=13)$ & & 0.01 & 0.02 \\
\hline Sludge 2 Industrial & 190805 & 0.12 & 0.16 \\
\hline $\begin{array}{l}\text { Sludge from biological treatment of industrial } \\
\text { waste water }\end{array}$ & 190812 & 0.02 & 0.04 \\
\hline Waste blasting material & 120117 & 0.03 & 0.07 \\
\hline Wood $(n=70)$ & 191207 & 0.04 & 0.04 \\
\hline WWTP RWZI dried sludge $(n=93)$ & 190805 & 0.01 & 0.01 \\
\hline Mean HI & & 0.22 & 0.27 \\
\hline $\mathrm{Nb} \mathrm{H}$ & & 1 & 2 \\
\hline Total & & 32 & \\
\hline
\end{tabular}




\section{HP 14 chronic}

\begin{tabular}{|c|c|c|}
\hline Sample code 1 & Sample code 2 & Worst case Hazard Index \\
\hline Asphalt rubble $(n=13)$ & 170301 or $170302 *$ & 0.00 \\
\hline Beton rubble $(n=13)$ & 170101 & 0.06 \\
\hline Boiler ashes incineration of non hazardous waste (n not known) & 190116 & 5.60 \\
\hline Bottom ash (n not known) & 190112 & 2.38 \\
\hline Bottom ashes 2 (n not known) & 190112 & 4.59 \\
\hline Car shredder residue $(n=10)$ & 191004 & 9.41 \\
\hline Domestic waste fine fraction & 200301 & 1.05 \\
\hline Fertilizer 1 & no code & 0.00 \\
\hline Fertilizer 2 & no code & 0.16 \\
\hline Filter cake 14 (textile WWT) & 190813 & 0.85 \\
\hline Filter cake 15 (paint WWT) & 190813 & 3.77 \\
\hline Filter cake 16 (food industry WWT) & 190813 & 0.39 \\
\hline Filtercake 17 (food industry WWT) & 190813 & 0.09 \\
\hline Filtercake 18 (food industry WWT) & 190813 & 0.10 \\
\hline Filtercake 19 (paint WWT) & 190813 & 3.04 \\
\hline Filtercake 20 (paint WWT) & 190813 & 2.49 \\
\hline Fly ash wood incinerator 190111 & 190114 & 5.72 \\
\hline Fly ashes from sludges incinerator $1(n=3)$ & 190114 & 2.08 \\
\hline Incineration ashes & $190114 / 12$ & 2.89 \\
\hline Industrial sludge $4(n=19)$ & 190812 & 0.29 \\
\hline Mixed rubble $(n=13)$ & 170107 & 0.07 \\
\hline MWWTP RWZI sludge & 190805 & 0.69 \\
\hline Refuse derived fuel $1(n=50)$ & 191210 & 0.45 \\
\hline Refuse derived fuel $2(n=500)$ & 191210 & 0.49 \\
\hline Shredder 2 & 191212 & 13.23 \\
\hline Shredder fluff & 191212 & 8.00 \\
\hline Sieved sand $(n=13)$ & & 0.09 \\
\hline Sludge 2 Industrial & 190805 & 1.18 \\
\hline Sludge from biological treatment of industrial waste water & 190812 & 0.16 \\
\hline Waste blasting material & 120117 & 0.26 \\
\hline Wood $(n=70)$ & 191207 & 0.35 \\
\hline WWTP RWZI dried sludge ( $n=93)$ & 190805 & 0.06 \\
\hline Mean $\mathrm{HI}$ & & 2.19 \\
\hline $\mathrm{Nb} \mathrm{H}$ & & 14 \\
\hline Total & & 32 \\
\hline
\end{tabular}


Page 46 / 51 


\section{Generic entries of the elements in the CLP}

\section{The "generic" entries are extracted from CLP Regulation Table 3.1 of Annex VI)}

\begin{tabular}{|c|c|c|c|c|}
\hline Element & Index No & $\begin{array}{l}\text { International Chemical } \\
\text { Identification }\end{array}$ & $\begin{array}{l}\text { Hazard Class and } \\
\text { Category Code(s) }\end{array}$ & $\begin{array}{l}\text { Hazard } \\
\text { Statement } \\
\text { Code(s) }\end{array}$ \\
\hline As & $033-002-00-5$ & $\begin{array}{l}\text { arsenic compounds, with the exception of those } \\
\text { specified elsewhere in this Annex }\end{array}$ & $\begin{array}{l}\text { Acute Tox. } 3 * \\
\text { Acute Tox. } 3 * \\
\text { Aquatic Acute } 1 \\
\text { Aquatic Chronic } 1 \\
\end{array}$ & $\begin{array}{l}\mathrm{H} 331 \\
\mathrm{H} 301 \\
\mathrm{H} 400 \\
\mathrm{H} 410\end{array}$ \\
\hline $\mathbf{B a}$ & $056-002-00-7$ & $\begin{array}{l}\text { barium salts, with the exception of barium } \\
\text { sulphate, salts of } 1 \text {-azo-2-hydroxynaphthalenyl } \\
\text { aryl sulphonic acid, and of salts specified } \\
\text { elsewhere in this Annex }\end{array}$ & $\begin{array}{l}\text { Acute Tox. } 4 * \\
\text { Acute Tox. } 4 *\end{array}$ & $\begin{array}{l}\mathrm{H} 332 \\
\mathrm{H} 302\end{array}$ \\
\hline $\mathbf{B e}$ & $004-002-00-2$ & $\begin{array}{l}\text { beryllium compounds with the exception of } \\
\text { aluminium beryllium silicates, and with those } \\
\text { specified elsewhere in this Annex }\end{array}$ & $\begin{array}{l}\text { Carc. 1B } \\
\text { Acute Tox. } 2 * \\
\text { Acute Tox. } 3 * \\
\text { STOT RE } 1 \\
\text { Eye Irrit. } 2 \\
\text { STOT SE } 3 \\
\text { Skin Irrit. } 2 \\
\text { Skin Sens. } 1 \\
\text { Aquatic Chronic } 2\end{array}$ & $\begin{array}{l}\text { H350i } \\
\text { H330 } \\
\text { H301 } \\
\text { H372 ** } \\
\text { H319 } \\
\text { H335 } \\
\text { H315 } \\
\text { H317 } \\
\text { H411 }\end{array}$ \\
\hline Cd & $048-001-00-5$ & $\begin{array}{l}\text { cadmium compounds, with the exception of } \\
\text { cadmium sulphoselenide ( } x \text { CdS.yCdSe), reaction } \\
\text { mass of cadmium sulphide with zinc sulphide } \\
\text { (xCdS.yZnS), reaction mass of cadmium } \\
\text { sulphide with mercury sulphide ( } x \text { CdS.yHgS), } \\
\text { and those specified elsewhere in this Annex }\end{array}$ & $\begin{array}{l}\text { Acute Tox. } 4 * \\
\text { Acute Tox. } 4 * \\
\text { Acute Tox. } 4 * \\
\text { Aquatic Acute } 1 \\
\text { Aquatic Chronic } 1\end{array}$ & $\begin{array}{l}\mathrm{H} 332 \\
\mathrm{H} 312 \\
\mathrm{H} 302 \\
\mathrm{H} 400 \\
\mathrm{H} 410\end{array}$ \\
\hline $\operatorname{Cr}(V I)$ & 024-017-00-8 & $\begin{array}{l}\text { chromium (VI) compounds, with the exception } \\
\text { of barium chromate and of compounds specified } \\
\text { elsewhere in this Annex }\end{array}$ & $\begin{array}{l}\text { Carc. 1B } \\
\text { Skin Sens. } 1 \\
\text { Aquatic Acute } 1 \\
\text { Aquatic Chronic } 1\end{array}$ & $\begin{array}{l}\text { H350i } \\
\text { H317 } \\
\text { H400 } \\
\text { H410 }\end{array}$ \\
\hline Hg & $080-002-00-6$ & $\begin{array}{l}\text { inorganic compounds of mercury with the } \\
\text { exception of mercuric sulphide and those } \\
\text { specified elsewhere in this Annex }\end{array}$ & $\begin{array}{l}\text { Acute Tox. } 2 * \\
\text { Acute Tox. } 1 \\
\text { Acute Tox. } 2 * \\
\text { STOT RE } 2 * \\
\text { Aquatic Acute } 1 \\
\text { Aquatic Chronic } 1 \\
\end{array}$ & $\begin{array}{l}\mathrm{H} 330 \\
\mathrm{H} 310 \\
\mathrm{H} 300 \\
\mathrm{H} 373 * * \\
\mathrm{H} 400 \\
\mathrm{H} 410\end{array}$ \\
\hline $\mathbf{P b}$ & $082-001-00-6$ & $\begin{array}{l}\text { lead compounds with the exception of those } \\
\text { specified elsewhere in this Annex }\end{array}$ & $\begin{array}{l}\text { Repr. 1A } \\
\text { Acute Tox. } 4 * \\
\text { Acute Tox. } 4 * \\
\text { STOT RE } 2 * \\
\text { Aquatic Acute } 1 \\
\text { Aquatic Chronic } 1\end{array}$ & $\begin{array}{l}\text { H360Df } \\
\text { H332 } \\
\text { H302 } \\
\text { H373 ** } \\
\text { H400 } \\
\text { H410 }\end{array}$ \\
\hline Sb & 051-003-00-9 & $\begin{array}{l}\text { antimony compounds, with the exception of the } \\
\text { tetroxide }\left(\mathrm{Sb}_{2} \mathrm{O}_{4}\right) \text {, pentoxide }\left(\mathrm{Sb}_{2} \mathrm{O}_{5}\right) \text {, trisulphide } \\
\left(\mathrm{Sb}_{2} \mathrm{~S}_{3}\right) \text {, pentasulphide }\left(\mathrm{Sb}_{2} \mathrm{~S}_{5}\right) \text { and those } \\
\text { specified elsewhere in this Annex }\end{array}$ & $\begin{array}{l}\text { Acute Tox. } 4 * \\
\text { Acute Tox. } 4 * \\
\text { Aquatic Chronic } 2\end{array}$ & $\begin{array}{l}\mathrm{H} 332 \\
\mathrm{H} 302 \\
\mathrm{H} 411\end{array}$ \\
\hline Se & $034-002-00-8$ & $\begin{array}{l}\text { selenium compounds with the exception of } \\
\text { cadmium sulphoselenide and those specified } \\
\text { elsewhere in this Annex }\end{array}$ & $\begin{array}{l}\text { Acute Tox. } 3 * \\
\text { Acute Tox. } 3 * \\
\text { STOT RE } 2 \\
\text { Aquatic Acute } 1 \\
\text { Aquatic Chronic } 1 \\
\end{array}$ & $\begin{array}{l}\mathrm{H} 331 \\
\mathrm{H} 301 \\
\mathrm{H} 373 * * \\
\mathrm{H} 400 \\
\mathrm{H} 410\end{array}$ \\
\hline TI & $081-002-00-9$ & $\begin{array}{l}\text { thallium compounds, with the exception of } \\
\text { those specified elsewhere in this Annex }\end{array}$ & $\begin{array}{l}\text { Acute Tox. } 2 * \\
\text { Acute Tox. } 2 * \\
\text { STOT RE } 2 * \\
\text { Aquatic Chronic } 2 \\
\end{array}$ & $\begin{array}{l}\mathrm{H} 330 \\
\mathrm{H} 300 \\
\mathrm{H} 373 * * \\
\mathrm{H} 411\end{array}$ \\
\hline $\mathbf{U}$ & $092-002-00-3$ & $\begin{array}{l}\text { uranium compounds with the exception of } \\
\text { those specified elsewhere in this Annex }\end{array}$ & $\begin{array}{l}\text { Acute Tox. } 2 * \\
\text { Acute Tox. } 2 * \\
\text { STOT RE } 2 \\
\text { Aquatic Chronic } 2 \\
\end{array}$ & $\begin{array}{l}\mathrm{H} 330 \\
\mathrm{H} 300 \\
\mathrm{H} 373 * * \\
\mathrm{H} 411\end{array}$ \\
\hline
\end{tabular}


Data for ecotoxicity

The Tables show the minimum $\mathrm{EC}_{50}$ and NOEC values extracted from the Portal of chemical substances from INERIS (http://www.ineris.fr/substances/fr/) of March 2013 and other data source among the species of metallic elements and metalloids. The elements in bold have generic entries. No further speciation work is required, as far as you can prove or judge that the "compounds specified elsewhere in this Annex" are not present in the waste.

Minimal $\mathrm{EC}_{50}$, maximal $\mathrm{M}_{\text {acute }}$ factor, maximal concentration limit and cut-off value for "worst case" approach in HP 14 acute ecotoxicity

\begin{tabular}{|c|c|c|c|c|c|c|}
\hline Element & $\begin{array}{c}\text { Acute } \\
\text { ecotoxicity } \\
\text { hazard } \\
\text { statement } \\
\text { code }\end{array}$ & $\begin{array}{c}\mathrm{EC}_{50} \min (\mathrm{mg} \\
\text { element/I) }\end{array}$ & Substance & $M_{\text {acute }}$ & $\begin{array}{c}\text { Concentration limit } \\
\text { acute }(\mathbf{m g} \\
\text { element } / \mathbf{k g})\end{array}$ & $\begin{array}{c}\text { Cut-off value } \\
\text { acute ( } \mathbf{m g} \\
\text { element/ } \mathbf{k g})\end{array}$ \\
\hline $\mathbf{H g}$ & $\mathrm{H} 400$ & 0.0007 & n.s. & 1000 & 250 & 1 \\
\hline Cd & $\mathrm{H} 400$ & 0.0034 & $\mathrm{CdCl}_{2}$ & 100 & 2500 & 10 \\
\hline $\mathrm{Cu}$ & $\mathrm{H} 400$ & $0.011 *$ & n.s. & 10 & 25000 & 100 \\
\hline As & $\mathrm{H} 400$ & 0.011 & $\mathrm{AsH}_{2} \mathrm{KO}_{4}$ & 10 & 25000 & 100 \\
\hline $\mathbf{P b}$ & $\mathrm{H} 400$ & 0.026 & $\mathrm{~Pb}\left(\mathrm{NO}_{3}\right)_{2}$ & 10 & 25000 & 100 \\
\hline $\operatorname{Cr}(\mathrm{VI})$ & $\mathrm{H} 400$ & 0.030 & $\mathrm{~K}_{2} \mathrm{Cr}_{2} \mathrm{O}_{7}$ & 10 & 25000 & 100 \\
\hline $\mathrm{Zn}$ & $\mathrm{H} 400$ & 0.032 & $\mathrm{ZnCl}_{2}$ & 10 & 25000 & 100 \\
\hline $\mathrm{Ni}$ & $\mathrm{H} 400$ & 0.060 & $\mathrm{NiCl}_{2}$ & 1 & 250000 & 1000 \\
\hline Se & $\mathrm{H} 400$ & not found & & 1 & 250000 & 1000 \\
\hline TI & - & 0.01 & n.s. & - & - & - \\
\hline $\mathbf{u}$ & - & 0.04 & n.s. & - & - & - \\
\hline $\mathrm{Be}$ & - & 0.1 & n.s. & - & - & - \\
\hline Sb & - & 1.77 & $\mathrm{SbCl}_{3}$ & - & - & - \\
\hline Ba & - & 14.5 & n.s. & - & - & - \\
\hline Mo & - & 29 & n.s. & - & - & - \\
\hline
\end{tabular}

n.s.: not specified

*: a lower value can be found in a European Commission - European Voluntary Risk Assessment Report (EU-VRAR) report but it is proposed to use this value instead

Minimal NOEC, maximal $M_{\text {chronic }}$ factor, maximal concentration limit and cut-off value for "worst case" approach in HP 14 chronic ecotoxicity

\begin{tabular}{|c|c|c|c|c|c|c|}
\hline Element & $\begin{array}{c}\text { Chronic } \\
\text { ecotoxicity } \\
\text { hazard } \\
\text { statement code }\end{array}$ & $\begin{array}{c}\text { NOEC min } \\
\mathbf{( m g / l )}\end{array}$ & Substance & $\mathbf{M}_{\text {chronic }}$ & $\begin{array}{c}\text { Concentration limit } \\
\text { chronic (mg } \\
\text { element/ kg) }\end{array}$ & $\begin{array}{c}\text { Cut-off value } \\
\text { chronic (mg } \\
\text { element/ } \mathbf{k g})\end{array}$ \\
\hline $\mathbf{H g}$ & $\mathrm{H} 410$ & 0.0001 & $\mathrm{n} . \mathrm{s}$. & 100 & 250 & 10 \\
\hline $\mathbf{C d}$ & $\mathrm{H} 410$ & 0.00016 & $\mathrm{CdCl}_{2}$ & 100 & 250 & 10 \\
\hline $\mathbf{S e}$ & $\mathrm{H} 410$ & 0.0018 & $\mathrm{Na}_{2} \mathrm{SeO}_{3}$ & 10 & 2500 & 100 \\
\hline $\mathrm{Cu}$ & $\mathrm{H} 410$ & 0.0022 & $\mathrm{CuCl}_{2}$ & 10 & 2500 & 100 \\
\hline $\mathbf{C r}(\mathbf{V I})$ & $\mathrm{H} 410$ & 0.0047 & $\mathrm{~K}_{2} \mathrm{Cr}_{2} \mathrm{O}_{7}$ & 10 & 2500 & 100 \\
\hline As & $\mathrm{H} 410$ & 0.0050 & $\mathrm{AsHNa}_{2} \mathrm{O}_{4}$ & 10 & 2500 & 100 \\
\hline
\end{tabular}




\begin{tabular}{|c|c|c|c|c|c|c|}
\hline $\mathbf{P b}$ & $\mathrm{H} 410$ & 0.0063 & n.s. & 10 & 2500 & 100 \\
\hline $\mathrm{Zn}$ & $\mathrm{H} 410$ & 0.01 & $\mathrm{ZnSO}_{4}$ & 10 & 2500 & 100 \\
\hline $\mathrm{Ni}$ & $\mathrm{H} 410$ & $0.01{ }^{*}$ & $\mathrm{NiCl}_{2}$ & 1 & 25000 & 1000 \\
\hline $\mathbf{B e}$ & $\mathrm{H} 411$ & 0.0038 & n.s. & - & 250000 & 10000 \\
\hline $\mathbf{S b}$ & $\mathrm{H} 411$ & 1.13 & $\mathrm{SbCl}_{3}$ & - & 250000 & 10000 \\
\hline $\mathbf{T l}$ & $\mathrm{H} 411$ & 0.002 & n.s. & - & 250000 & 10000 \\
\hline $\mathbf{U}$ & $\mathrm{H} 411$ & 0.0007 & n.s. & - & 250000 & 10000 \\
\hline $\mathbf{B a}$ & - & 2.9 & n.s. & - & - & - \\
\hline Mo & - & 54 & n.s. & - & - & - \\
\hline
\end{tabular}

n.s.: not specified

*: a lower value can be found in a European Commission - European Voluntary Risk Assessment Report (EU-VRAR) report but it is proposed to use this value instead 


\section{Tests for HP 1 'Explosive', HP 2 'Oxidising' and HP 3 'Flammable'}

Tests for $\mathrm{H} 1, \mathrm{H} 2$ and $\mathrm{H} 3$ applicable to waste in France, and proposed for HP 1, HP 2 and HP 3.

\begin{tabular}{|c|c|c|}
\hline H properties & Definition of "product" & Methods \\
\hline H1 Explosive & $\begin{array}{l}\text { Substances and preparations which may } \\
\text { explode under the effect of flame or which } \\
\text { are more sensitive to shocks or friction } \\
\text { than dinitrobenzene }\end{array}$ & $\begin{array}{l}\text { EC Method A14: thermal and mechanical sensitivities } \\
\text { (impact and friction) }\end{array}$ \\
\hline H2 Oxidizing & $\begin{array}{l}\text { Substances and preparations which, in } \\
\text { contact with other substances, particularly } \\
\text { flammable substances, present a highly } \\
\text { exothermic reaction }\end{array}$ & $\begin{array}{l}\text { Gas: Method ISO } 10156 \text { (paragraph 5) } \\
\text { Liquids: UN O2 test (liquid oxidizers) } \\
\text { Solids: UN test O1 (oxidizing solids) }\end{array}$ \\
\hline \multirow{5}{*}{ H3-A Highly flammable } & $\begin{array}{l}\text { Substances and preparations: } \\
\text { in liquid form, with a flash point below } 21 \\
{ }^{\circ} \mathrm{C} \text {, or }\end{array}$ & EC method A9 \\
\hline & $\begin{array}{l}\text { which may become hot and finally catch } \\
\text { fire in air at ambient temperature without } \\
\text { any input of energy, or }\end{array}$ & $\begin{array}{l}\text { Test UN N2 (pyrophoric solids) or UN N3 (pyrophoric } \\
\text { liquids) and UN N4 (solid, self-heating) }\end{array}$ \\
\hline & $\begin{array}{l}\text { In the solid state, which may readily catch } \\
\text { fire after brief contact with a source of } \\
\text { ignition and which continue to burn or to } \\
\text { be consumed after removal of the source } \\
\text { of ignition, or }\end{array}$ & Test UN N1 (flammable solids) \\
\hline & $\begin{array}{l}\text { in the gaseous state, which are flammable } \\
\text { in air at normal pressure, or }\end{array}$ & $\begin{array}{l}\text { A11 EC method or a method of ISO } 10156 \\
\text { (paragraph 4) standard }\end{array}$ \\
\hline & $\begin{array}{l}\text { which, in contact with water or damp air, } \\
\text { evolve highly flammable gases in } \\
\text { hazardous quantities. }\end{array}$ & $\begin{array}{l}\text { Test UN N5 (substances which, in contact with water, } \\
\text { emit flammable gases) }\end{array}$ \\
\hline H3-B Flammable & $\begin{array}{l}\text { Liquid substances and preparations having } \\
\text { a flash point equal to or greater than } 21^{\circ} \mathrm{C} \\
\text { and less than or equal to } 55^{\circ} \mathrm{C}\end{array}$ & EC method A9 \\
\hline
\end{tabular}

In practice, the test UN N1 (flammable solids) and EC method A9 (flash point of liquids) are the most frequent. An alternative is to use the analytical package results to detect substances with a flash point $<55^{\circ} \mathrm{C}$. 
Tests for ecotoxicity (Pandard and Römbke (2013)

\begin{tabular}{|c|c|c|c|c|}
\hline Test & Endpoints & $\begin{array}{l}\text { EC or LID limit } \\
\text { values: the waste } \\
\text { is HP } 14 \text { if }\end{array}$ & Duration & Standard \\
\hline \multicolumn{5}{|l|}{ Aquatic tests } \\
\hline $\begin{array}{l}\text { Inhibition of the light } \\
\text { emission of Vibrio fischeri } \\
\text { (Luminescent bacteria test) }\end{array}$ & $\begin{array}{l}\text { Eluate concentration which results in } 50 \% \text { inhibition } \\
\text { of light emission }\left(\mathrm{EC}_{50}\right) \text {, or } \\
\text { Dilution step at which light emission is inhibited by } \\
\text { more than } 20 \% \text { in comparison to the control }\end{array}$ & $\begin{array}{l}\mathrm{EC}_{50} \leq 10 \% \\
\mathrm{LID}>8\end{array}$ & $30 \mathrm{~min}$ & $\begin{array}{l}\text { EN ISO } \\
11348- \\
3(2007)\end{array}$ \\
\hline $\begin{array}{l}\text { Freshwater algal growth } \\
\text { inhibition test with } \\
\text { Desmodesmus subspicatus } \\
\text { or Pseudokirchneriella } \\
\text { subcapitata }\end{array}$ & $\begin{array}{l}\text { Eluate concentration which results in } 50 \% \text { inhibition } \\
\text { of population growth }\left(\mathrm{EC}_{50}\right) \text {, or } \\
\text { Dilution step at which population growth is inhibited } \\
\text { by more than } 25 \% \text { in comparison to the control }\end{array}$ & $\begin{array}{l}\mathrm{EC}_{50} \leq 10 \% \\
\mathrm{LID}>8\end{array}$ & $72 \mathrm{~h}$ & $\begin{array}{l}\text { EN ISO } 8692 \\
(2012)\end{array}$ \\
\hline $\begin{array}{l}\text { Inhibition of the mobility of } \\
\text { Daphnia magna - }\end{array}$ & $\begin{array}{l}\text { Eluate concentration which results in } 50 \% \text { inhibition } \\
\text { of mobility }\left(\mathrm{EC}_{50}\right) \text {, or } \\
\text { Dilution step at which mobility is inhibited by more } \\
\text { than } 20 \% \text { in comparison to the control }\end{array}$ & $\begin{array}{l}\mathrm{EC}_{50} \leq 10 \% \\
\mathrm{LID}>8\end{array}$ & $48 \mathrm{~h}$ & $\begin{array}{l}\text { EN ISO } 6341 \\
(2012)\end{array}$ \\
\hline \multicolumn{5}{|l|}{ 2. Terrestrial tests } \\
\hline $\begin{array}{l}\text { Soil contact test with } \\
\text { Arthrobacter globiformis } \\
\text { (bacteria contact test) }\end{array}$ & $\begin{array}{l}\text { Waste concentration which results in } 50 \% \text { inhibition } \\
\text { of enzyme activity }\left(\mathrm{EC}_{50}\right) \text {, or } \\
\text { Dilution step at which enzyme activity is inhibited by } \\
\text { more than } 30 \%\end{array}$ & $\begin{array}{l}\mathrm{EC}_{50} \leq 10 \% \\
\mathrm{LID}>8\end{array}$ & $6 \mathrm{~h}$ & $\begin{array}{l}\text { ISO/DIS } \\
10871 \\
(2008)\end{array}$ \\
\hline $\begin{array}{l}\text { Effects of chemicals on the } \\
\text { emergence and growth of } \\
\text { higher plants (Avena } \\
\text { sativa, Brassica napus) }\end{array}$ & $\begin{array}{l}\text { Waste concentration which results in } 50 \% \text { inhibition } \\
\text { of growth }\left(\mathrm{EC}_{50}\right) \text {, or } \\
\text { Dilution step at which growth is inhibited by more } \\
\text { than } 30 \%\end{array}$ & $\begin{array}{l}\mathrm{EC}_{50} \leq 10 \% \\
\mathrm{LID}>8\end{array}$ & $14 d$ & $\begin{array}{l}\text { ISO } 11269-2 \\
(2012)\end{array}$ \\
\hline $\begin{array}{l}\text { Avoidance test with } \\
\text { earthworms (Eisenia } \\
\text { andrei/fetida) }\end{array}$ & $\begin{array}{l}\text { Waste concentration which affects behaviour by } 50 \% \\
\left(E C_{50}\right) \text {, or } \\
\text { Dilution step at which behaviour is impacted by } \\
\text { more than } 40 \%\end{array}$ & $\begin{array}{l}\mathrm{EC}_{50} \leq 10 \% \\
\mathrm{LID}>8\end{array}$ & $48 \mathrm{~h}$ & $\begin{array}{l}\text { ISO } 17512-1 \\
(2007)\end{array}$ \\
\hline
\end{tabular}

